Article

\title{
Analysis and Potential Application of the Maturity of Growth Management in the Developing Construction Industry of a Province of China: A Case Study
}

\author{
Jingxiao Zhang ${ }^{1, *}$, Hui $\mathrm{Li}^{2, *}$ and Steve Hsueh-Ming Wang ${ }^{3}$ \\ 1 School of Economics and Management, Chang'an University, Middle Section of South Second Ring Road, \\ Xi'an 710064, China \\ 2 School of Civil Engineering, Chang'an University, No. 161, Chang'an Road, Xi'an 710061, China \\ 3 College of Engineering, University of Alaska Anchorage, 2900 Spirit Dr., Anchorage, AK 99504, USA; \\ hswang@alaska.edu \\ * Correspondence: jxzhangchd@163.com (J.Z.); lihui9922@chd.edu.cn (H.L.)
}

Academic Editor: Yongrok Choi

Received: 19 July 2016; Accepted: 11 January 2017; Published: 19 January 2017

\begin{abstract}
Construction industry is one of the major drivers of the economic sustainability of China's provinces. An investigation of the status of the construction industry in China is needed to find out its maturity and health. The results of this investigation may help China define the impact factors required in order to promote the growth level of its construction industry. This research assesses the growth level of the construction industry in Shaanxi Province, China. This study utilizes both the original average score method and the newer entropy method to analyze the growth level of the construction industry based on its growth management model and growth drivers. An empirical survey of this research includes 123 construction companies in Shaanxi Province. The results show that the entropy method is better than the average score method to use when analyzing the maturity status of a local industry for future development. The maturity level of Shaanxi's construction industry lies on the second tier in a four-tier ranking system. The advanced professional skills of project management are critically needed for future growth. Brand building is the most important factor needed to drive up Shaanxi's construction industry. Standardization, knowledge management through lessons learned, and cost management for budget control by using information systems are required for Shaanxi's construction project management. The Excellent Project Management Model of China is often used in Chinese project knowledge management. After maturity analysis, China's local industries would be able to develop a sustainable strategy for optimizing their outcomes by removing the hurdles preventing future growth.
\end{abstract}

Keywords: China's construction industry; maturity; economic sustainability; Excellent Project Management Model

\section{Introduction}

China's construction sector is now crucial to the country's economic development, while competition has become significant and aggressive. Although China's construction market is fairly new, it is already the largest in the world in terms of development potential and profitability. China's government applies its central, provincial and local management model to regulate its construction industry. The Ministry of Construction is the main supervisor in the sector through the effective application of three major laws: construction law, contract law and tendering and bidding law. These regulations allow companies to operate as commercial entities, mainly through competitive bidding [1].

In general terms, China's construction sector is comprised of companies primarily engaged in the construction of buildings and other structures, additions, alterations, renovations, installations, 
maintenance, and repairs. China's construction industry includes three distinct categories of enterprises: state-owned companies, urban and rural collectives, and rural construction teams, and despite the declining significance of foreign direct investment in the sector, the latest official data also consider foreign-funded companies as representative elements in the sector's growth.

As one of the most protected industries, which include automobiles, civil aviation, telecommunications, construction, steel, insurance, and energy in China, the construction industry undergoes sophisticated restructuring despite the general need to follow new patterns of industrial growth management. China's construction sector very much depends on its national macroeconomic policy, which in recent times has led to an upsurge of domestic demand and investment in infrastructure, more precisely in construction materials, equipment, and design services. Local governments, which tend to be the major investors in infrastructure, are the largest end users of construction materials and equipment.

However, China's construction sector is still labor-intensive, whereas it needs to gradually move into being technology-intensive in order to increase its international competitiveness [2]. Despite the growth of construction companies in China, there are only a few large and profitable enterprises that can influence and lead the industry or otherwise compete in the international market. From the perspective of competitiveness, the development of the construction industry is extremely unbalanced among the provinces in that a few are very developed, yet most are underdeveloped. Thus there is a development gap between the provinces as two provinces are the most developed in the construction industry and ten provinces are still developing; Shaanxi Province belongs to the latter category. Thus the growth management of China's construction industry needs to emphasis each province's context in order to understand its status in the transition period and to achieve a comprehensive upgrade.

This research proposes a new theoretical framework to analyze the maturity status of a local industry for future development and compares the results of the original growth management model with the new entropy method. The research results may be a good foundation in understanding the transition process of construction industry management in China when developing its management strategy. They are particularly useful to similar industries which may need improvement in developing their own approaches to managing economic sustainability.

The literature review in Section 2 surveys the drivers of the construction industry and growth management model as it applies to China. Section 3 provides the methodology of this research. Section 4 applies the methodology to analyze the growth stage of the construction industry and the corresponding top influencing factors. Section 5 presents the conclusions and highlights the implications for construction industry maturity analysis in a transitional economy.

\section{Literature Review}

Due to the widespread construction and overheating process derived from excessive investment, effective growth management in the civil engineering sector has been particularly imperative in the past decade. As construction industry managers often cannot clearly understand their own industry's status, it creates an iterating process throughout its industrial growth, and of course, internal barriers may be dominant caused by government policy initiative. According to previous research [2-11], several causes may be put forward to explain the barriers of construction industry growth management in the transition process.

First, the traditional argument is that a fair environment for innovation, specific brand-building strategy, capital-intensive project management, and project management information system are still in their infancy. These are the main factors restricting the transformation and upgrading of the construction industry. This argument explains the reason for much of the slow improvement and low implementation efficiency of industrial growth at the time of transition and shortly after that period. However, since the modernization of the construction market and the adoption of benchmarked project management, the explanatory power of this traditional argument decreases, although it does not vanish. Second, the barrier of construction industry growth management may be caused by the 
lack of skilled workers at the provincial level. A typical example of this is the low level of low carbon building technology investment [12-14] and its corresponding lack of talent support [15].

Additionally, considering the crucial importance of the construction industry in China's path to economic transition, the 2014 guidelines for promoting the development and reform of the construction industry issued by the Ministry of Housing and Urban-Rural Development of the People's Republic of China (MOHURD, P. R. China) state that provinces, autonomous regions, and municipalities may use the actual situation to propose the self-augmenting reform policies and measures in order to support the transformation of construction enterprise. This should then achieve the success results of sustainable growth. According to the thirteenth five-year plan transition pilot program in construction, Shaanxi Province has also been listed to carry out the pilot reform and development of its construction industry, complying with the 2014 guidelines of MOHURD, P. R. China.

Stubbs and Cocklin (2008) discuss organizational development needs in view of the balance between economic and environmental impacts by using the sustainability business model [16]. Wang (2016) has developed a procedure for the analysis of sustainable development, which includes accountability, predictability, balanceability, and policy (APBP), as shown in Figure 1 [17]. In this research, focus has been placed on the maturity of the construction industry based on the accountability analysis of the maturity of this industry. The rising need to quantitatively assess the levels and target the impact factors as a way of improving the construction industry's sustainable development has become one of the dominant best practice requirements in the construction industry over recent years in both a national and international context $[18,19]$.

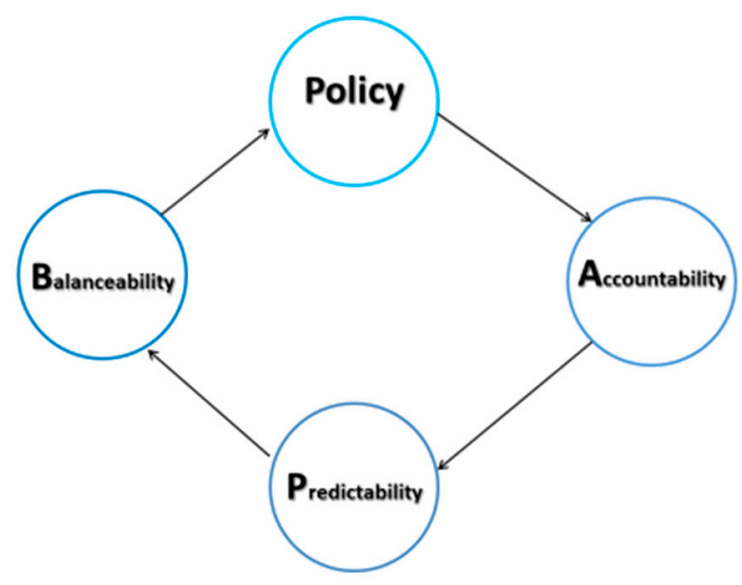

Figure 1. Cycle of accountability, predictability, balanceability, and policy (APBP) (Wang, 2016) [20].

Attention should be given to the fact that there is a clear gap between the different levels in the process of organizational maturity, and as a result, a methodology is needed to predict the level of the local industry $[21,22]$. The method of using the targeted impact factors may be far too generic to be utilized by practitioners seeking to implement the specific growth management of the construction industry in order to ensure its sustainable development [23,24]. Usually, companies in the transition phase cannot see their way to upgrade to the next level $[19,25-33]$. The growth management model (GMM) has been adopted to form an integrated organizational diagnosis framework to analyze the growth management of the petroleum industry in China [34].

Determination of the level of growth in China's construction industry has a political connotation [3]. In recent years, policy makers have repeatedly designed strategic programs to trigger growth at the central, provincial, and local levels. This research provides a theoretical framework and case study to explore the growth of China's construction industry at the provincial level. 


\subsection{Growth Driversof the Construction Industry}

The growth drivers of the construction industries, such as the influences of technological innovation and strategies to transparently build up a company's drivers in order to overcome the difficulties in the transformation period, have caught the attention of researchers [35-37]. Growth drivers also may include renovating construction patterns, integrating external information, implementing project knowledge management, and developing the brand [19,38-41]. The competitive advantages of the updated industry are based on the efficient use of internal resources, such as capital, workforce, technological innovation, and knowledge integration of brand building. For example, technological innovation may lead the transformation and improve the capability of enterprises [42,43]. The acquisition and implementation of talent helps enterprise transformation [44]. Undoubtedly, a well-designed brand is needed to provide values to consumers in the construction service market. The brand of a construction enterprise also requires high-quality projects, outstanding corporate culture, thoughtful customer service, and advanced management systems.

On the micro level, construction companies may have similar drivers in the growth process. For example, Han and Ofori (2001) [3] have studied the relationship between the development of the construction industry and local economic growth. Iammarino et al. (2012) [45] have researched the relationship between companies' technological capabilities and their locations. Dick and Payne (2005) [46] and Herliana (2015) [47] have studied local development and the growth of clusters of small and medium enterprises. They all state that at the local level, growth could be accelerated by certain factors. They also note that with a clear process, construction industry growth management is increasingly recognized as a central competitive advantage in embracing sustainability. However, Dick et al., argue that there is compelling evidence that as the construction industry wrestles with the challenge of building a sustainable organization, it should clearly know at what growth level it is and then focus on the core issues in order to proceed with the appropriate steps. Nevertheless, for local construction companies, there is a lack of systematic framework for growth drivers that can be used effectively in practice to analyze the growth level of the construction industry. Thus, it is urgent to thoroughly understand the sustainable processes to implement change. This is because of the following: (a) Growth management of the local construction industry is needed to justify the enterprises' growth drivers and to realize that their levels are influenced by their specific impact factors; (b) Impact factors are targeted in the corresponding phase of construction industry management; and (c) Successful countermeasures are needed to iterate industrial growth management through local construction company feedback. As described above, the growth path of the local construction industry has been established for industrial policymakers in order that they achieve self-augmentation of their industry management. This provides a quantitative way to service a repeatable and scalable industry growth management model of sustainable construction industry.

Laihonen et al. (2015) developed case-specific cornerstones of growth-oriented knowledge management. The results of their research show that there are two knowledge issues that arise when dealing with growth management. The first issue concerns whether or not an organization has the needed knowledge resources to enable growth, and the second issue is the need for management to have relevant and real-time information in order to make informed decisions [48]. AlQahtany et al., used Delphi techniques to propose a framework of sustainable development that focused on environmental, social, economic and urban planning issues [49]. However, these models are neither focused on the construction industry nor can be used to analyze its maturity. McIntyre [20] explains a process for finding out the appropriate level of the growth management model (GMM) through a consortium of industry advisory boards, committees, and councils; the American Council for Construction Education has chosen this model as a standard. This model pays much attention to internal sustainable management in order to pursue an organization's growth and has been widely facilitated in organizational process management, such as sustainable growth management of organizational diagnosis [34]. Thus, our research uses growth drivers in China's construction industry plus GMM to form a theoretical framework. Our study also implements the data of 
previous research to further analyze the growth path position of construction industry management, which forms a complementary profile of the internal driver levels to explain Shaanxi's construction industry management.

\subsection{Growth Management Model (GMM)}

Growth managementis one core part of the sustainable growth of an industry, which is increasingly recognized as a central determinant for economic sustainability. In order to analyze the growth management of an industry, Charles McIntyre (2015) [20] suggests using an industry advisory board (IAB) to propose an IAB GMM model for analyzing the organizational growth stage. Like Charles McIntyre's statement, the GMM framework roots itself in basic management theory which is applicable to any business or organization. Focusing on the internal and evolutionary growth which occurs within industry, the GMM model is generic in nature and refers to any industry. Charles McIntyre was aware of this and provided a structured and sequential approach to improving managerial proficiency with the ultimate goal of enhancing outcomes by means of models that are similar to IAB GMM. As a managerial instrument, the GMM model is designed to enhance the proficiency of an organization which is attempting to improve organizational outcomes.

As an organization's managerial proficiency improves, organizational outcomes increase before reaching new stability zones/levels. Transition periods may result in interpersonal conflicts because of new expectations and higher anticipated efficiencies. During the transition periods, IAB members are typically asked to step out of their personal comfort zones and meet new challenges. In this process, GMM provides a fundamental theory to understand the significance of effective managerial proficiency. In an organization's GMM framework, the vertical axis represents managerial proficiency, and the horizontal axis relates to an organization's outcomes. The relationship between managerial proficiency and organizational outcomes is expressed by a series of plateau levels, such as IAB Level I, which are linked by transition periods. During the period of transition, the organization needs to change until it approaches the next managerial proficiency level. These four management plateaus represent the IAB GMM model outcomes which can be achieved at each level of managerial proficiency. These plateaus are stability levels where the IAB outcomes match the organization's managerial proficiency exactly, as shown in Figure 2. Consistent with the generic thinking of the IAB GMM, this research modifies the corresponding four levels of construction industry growth management to form a new integrated diagnostic model for local construction industry transition. As the integrated model indicates in Figure 2, the vertical axis represents managerial proficiency, and the horizontal axis shows instrument scores.

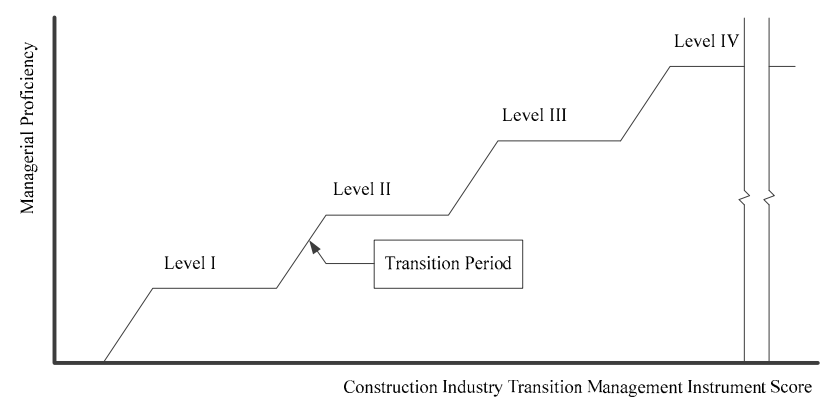

Figure 2. Incorporating growth management model (GMM) into local construction industry transition.

In order to respond to the growth level question of the construction industry, McIntyre has adopted the concepts of the framework of GMM [20] to match the construction industry's transition to a stage of sustainable economic development. The research of Zhang et al. (2016) has integrated IAB GMM into an extended Weisbord's Six-Box Model to form a sustainable growth diagnosis framework, which has been used to investigate one of China Petro sub-companies as an empirical case study [34]. According 
to existing research of growth drivers, four levels of construction industry growth management have been redeveloped by renovating construction patterns, integrating external information, implementing project knowledge management, and building the brand, which are all primary components of managerial proficiency of construction industry transition needed for sustainable development. In addition, construction industry transition outcomes are defined as the number and quality of best practices conducted by local construction industry within these four proficiency levels.

\subsection{Analysis of the Maturity of Growth Management}

This research has developed a theoretical framework of the general underlying mechanisms of maturity analysis as shown in Figure 3. Within this framework it can be seen that transition process description and quantitative assessment have the same implications for the development of a local construction industry. The goals of the research approach are to create an understanding of the theoretical framework of construction industry growth management in the transition period and to structure the findings obtained in this case study.

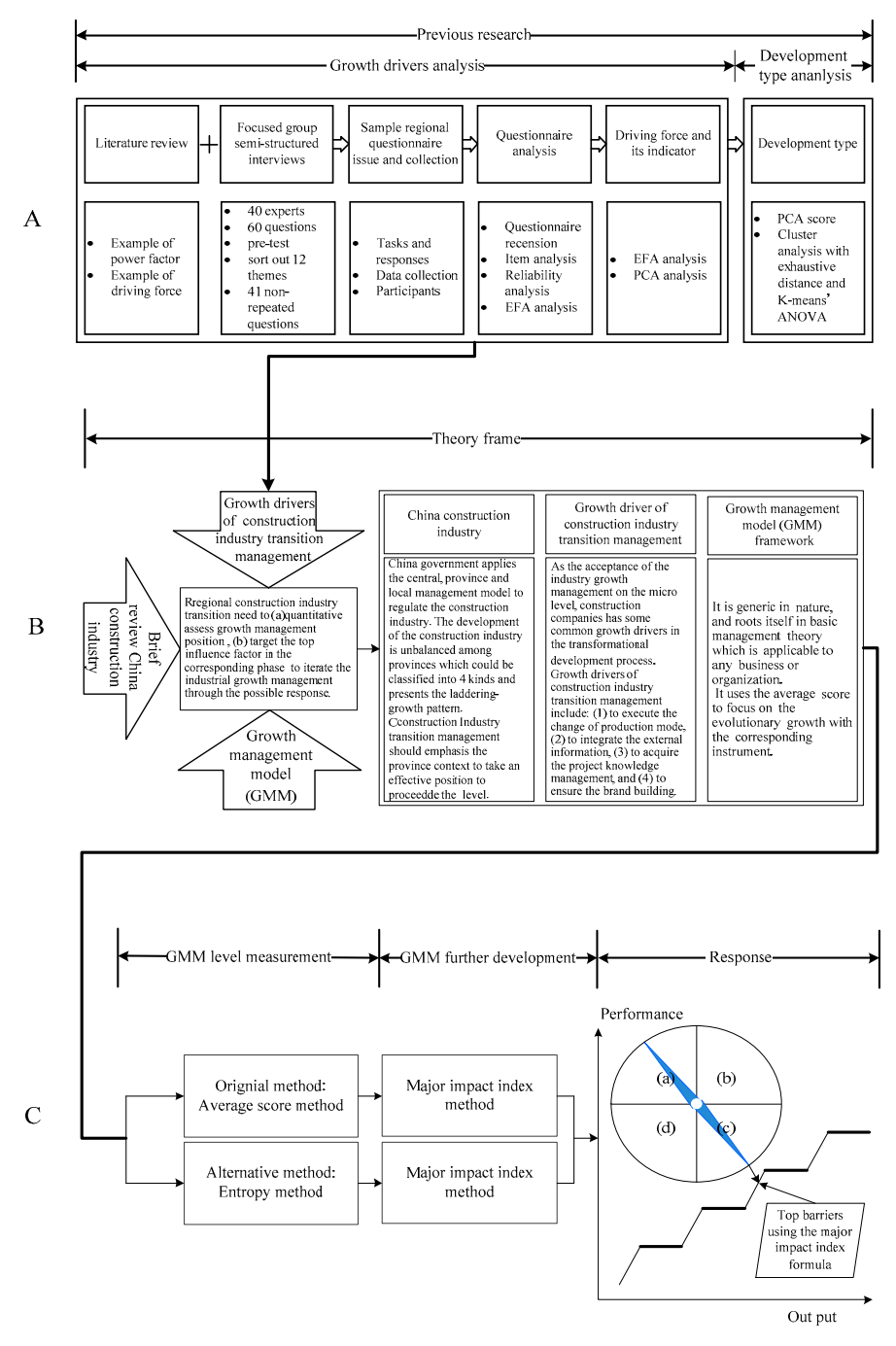

Figure 3. Research design. Note 1: (A) represents the previous studies and growth driver analyses that were adopted in this research; (B) represents the theoretical framework integration process; and (C) represents the test process of theoretical framework. Note 2: There are four growth drivers in the response wheel. Driver (a) represents implementation level of transformational development; Driver (b) represents external information integration; Driver (c) represents project knowledge management; and Driver $(\mathrm{d})$ represents corporate brand building support. 


\section{Methodology}

In order to justify the validity of the original GMM framework by using an average score method, according to the American Council of Construction Education (ACCE), we chose the entropy method as the proposed alternative to comparatively analyze the growth management position in order to target the transition step in the sustainable development of the construction industry transition process. The entropy method [50-52] is an objective approach reflecting the disorder degree of information in not only information theory but also in the expansion of social and economic areas [50,51,53-55] where the weights of individual indicators are determined by calculating the entropy and entropy weight. The greater the entropy is, the smaller the corresponding entropy weight. If the entropy weight is zero, it provides no useful information to the decision-maker, and this indicator may be removed. The amount of useful information that the target provides to the decision-maker is objective. Thus, using the entropy method to determine index weights could reflect an objective and realistic information-derived GMM system of construction industry transition.

\subsection{Average Score Method}

According to Charles McIntyre (2015), the main steps in obtaining the average score to evaluate the GMM Level of the local construction industry are shown as follows [20]:

(1) Calculating the average score of total samples

Suppose there are $m$ units and $n$ indicators to be evaluated to establish the sum in Equation (1).

$$
Z F_{i}=\sum_{t=1}^{n} f_{s t}
$$

where $s=1,2,3, \ldots, m ; t=1,2,3, \ldots, n ; Z F_{s}=$ the score sum of $s$ th sample; $f_{s_{t}}=$ the $t$ th index score of $s$ th sample. Then the average score of $m$ units is calculated in Equation (2).

$$
f=\sum_{s=1}^{m} Z F_{s} / m
$$

(2) Grading the GMM level of the local construction industry

When the average score is calculated, we apply it to grade the WSBGMM level.

According to the IABGMM model [20], suppose that there is $K=5$ (where $A=5$ represents strong disagreement to $E=5$ representing strong agreement) scaling of each indicator in each unit, then there are $5(K=5)$ levels to be graded for the sample. The scope of each level is shown in Table 1.

Table 1. The scope of each level in the growth framework of construction industry growth management using the average score method.

\begin{tabular}{ccccc}
\hline Level & I & II & III & IV \\
\hline Scope & $n \times[1,2)$ & $n \times[2,3)$ & $n \times[3,4)$ & $n \times[4,5]$ \\
\hline
\end{tabular}

Note: $n$ represents the number of indicators in $m$ units. Source: Compiled by the authors according to the IABGMM level calculation proposed by Charles McIntyre (2015) [20].

In the case of the average score method, it is assumed that the index weight probability of each sample at each level is equally allocated to generate the total sample level in the WSBGMM model. Actually, the index weight is objectively constrained by the sample score, which is the reason why we have used another method, namely the entropy method, to calculate the WSBGMM level to arrive at more accurate assessment results. 


\subsection{Entropy Method}

The main four steps of entropy method [50,56] are shown as follows:

Step 1: The formation of the evaluation matrix

Suppose there are also $m$ units and $n$ indicators to be evaluated in order to establish the original data matrix in Equation (3).

$$
R=\left(r_{n}\right)_{m \times n} \quad(s=1,2 \ldots, m ; t=1,2 \ldots, n)
$$

where $r_{s t}$ represents the actual value of the $t$ th index of $s$ th unit.

Step 2: The standardization of the evaluation matrix

The following equation is used to normalize the matrix $B$,

$$
B=\left(b_{n}\right)_{m \times n}(s=1,2 \ldots, m ; t=1,2 \ldots, n) \text { with } b_{s t}=\frac{r_{s t}-r_{\min }}{r_{\max }-r_{\min }}
$$

where $r_{\max }$ and $r_{\min }$ represent the maximum and minimum values respectively for the evaluation unit.

If indicator is the positive tropism (+)

$$
b_{s t}=\frac{r_{s t}-r_{\min }}{r_{\max }-r_{\min }}
$$

If indicator is the negative tropism (-)

$$
b_{s t}=\frac{r_{\max }-r_{s t}}{r_{\max }-r_{\min }}
$$

Step 3: The calculation of the entropy

The entropy of the system can be defined by using the following calculations:

$$
H_{t}=-\left(\sum_{s=1}^{m} f_{s t} \ln f_{s t}\right) / \ln m \quad(s=1,2 \ldots, m ; t=1,2, \ldots n)
$$

where, $f_{s t}=b_{s t} / \sum_{s=1}^{m} b_{s t}$ if $f_{s t}=0$, redefine the $f_{s t}$ as:

$$
f_{s t}=\left(1+b_{s t}\right) / \sum_{s=1}^{m}\left(1+b_{s t}\right)
$$

Step 4: The calculation of the entropy weight

$$
\mathrm{w}=\left(\omega_{t}\right)_{1 \times n}, \omega_{t}=\left(1-H_{t}\right) /\left(n-\sum_{t=1}^{n} H_{t}\right) \text { with } \sum_{t=1}^{n} \omega_{t}=1
$$

Step 5: Use to Entropy weight to calculate the score of WSBGMM level

$$
s f=\sum_{i=1}^{n} \omega_{i} f_{i}
$$

where, $\omega_{i}=$ the entropy weight of the $i$ th index, and $f_{i}$ the score of the $i$ th index. 
Step 6: Grade the level

According to the average score method above, the entropy method to grade the GMM level of the construction industry growth management is shown in Table 2.

Table 2. Scope and level of the growth framework of the construction industry using the entropy method.

\begin{tabular}{ccccc}
\hline Level & I & II & III & IV \\
\hline Scope & {$[1,2)$} & {$[2,3)$} & {$[3,4)$} & {$[4,5]$} \\
\hline
\end{tabular}

Source: Compiled by the authors according to the grading rubric of the IABGMM level proposed by Charles McIntyre (2015) [20].

\subsection{Targeted with Impact Factor}

As stated previously, looking at the top impact barriers and finding targeted solutions in the current organizational level is a good way to promote a sustainable path for an organization. This research uses the major impact index formula [52,57-59] to generate and compare the impact extent of the indices, which are shown Equation (9).

$$
A_{i}=\omega_{i} d_{i} / \sum_{i=1}^{n} \omega_{i} d_{i} \times 100 \%
$$

$A_{i}$ represents the indices' impact extent, $\omega_{i}$ represents the index entropy weight, $d_{i}$ represents the index standardization value, and $n$ represents the index number in the evaluation system of WSBGMM.

As to the use of the average score method to calculate the top impact barriers, the index is allocated to the average weight. Thus the top impact barrier formula with the average score method is shown in Equation (10).

$$
A_{i}=\frac{d_{i}}{\sum_{i=1}^{n} d_{i}} \times 100 \%
$$

\section{Implementation}

\subsection{Data Collection}

This research uses data collection from prior research that focused on obtaining the understanding of growth drivers that may help to promote the transformation of the local construction industry at the company level. In addition, China's economy is driven primarily by the policy and management of local governments, resulting in the transitional status of the local construction industry. Thus, using a survey design, we collected data from 123 local construction companies located in China's Shaanxi Province to explain the growth level of its construction industry growth management. The Shaanxi Construction Association has been responsible for the forum of construction industry growth management annually supported by the provincial government in Shaanxi. With the help of the Shaanxi Construction Association, we randomly selected 1200 companies from the Shaanxi 2014 Yellow Pages Commercial/Industrial Telephone Directory [59-62]. We made telephone calls to the top administrator of each company to explain the purpose of the study and to solicit agreement for survey participation. Of the 1200 companies, 300 agreed to participate. We then hand delivered a total of 300 questionnaires to the top administrator in each company. A telephone follow-up was conducted within two weeks to make sure that it was the top administrator (i.e., general or deputy-general manager) who provided the information. In many cases, the research company sent representatives to meet the top administrators of the companies to explain how the data would be used, to answer any questions, and to collect the finished questionnaires. This was an important step toward obtaining high-quality data in China [63,64]. Overall, a total of 145 questionnaires were issued, of which 123 were completed 
correctly. With an $84.83 \%$ response rate, the data collection met the requirement of sample size (i.e., at least 100) in order to analyze the common problems in economic and social areas [65,66].

Following the prior research design shown in Figure 3 in Section 2.3, we developed a questionnaire with (a) item analysis ( $T$-test $(p<0.05)[65,66]$ ); (b) reliability analysis (Cronbach's $\alpha>0.80)$; (c) item total correlation analysis, the threshold value of which was conducted between 0.3 and 0.5 [66]; (d) exploratory factor analysis (EFA) $(\mathrm{KMO}>0.9$ and Eigenvalue $>1)$; and (e) principle component analysis (PCA) with SPSS 22 software (Appendixs A-J). In addition, in order to determine whether nonresponse bias was present in the study, we compared early respondents with late respondents on the key constructs. Chi square tests showed that no significant differences existed between the early and the late respondents with regard to company characteristics. In addition, t-test results indicated that there were no significant differences between the earlier and later respondents on the measures of construction industry growth management. Thus, nonresponse bias was not a problem in this study.

Our final questionnaire of Shaanxi's construction industry growth management contained 16 questions (Appendix B). In the formal questionnaire, most items were evaluated on a five-point ratio scale $(1=$ very important to $5=$ not very important), except for several specific options. The statistical measurements of instrument development are described in Table 3 below.

In Shaanxi Province, we administered the questionnaire in Chinese. To ensure that the meaning of all questionnaire items in the Chinese version were the same as those in the original English version, we translated all the questions into Chinese and then back-translated them into English following the procedure that Chung-Leung (2005) [67] andLi (2006) [68] suggest.

Table 3. Overview of items and principle components in the final questionnaire of Shaanxi's construction industry.

\begin{tabular}{|c|c|c|c|c|}
\hline Original Question No. & Item & $\begin{array}{l}\text { Principle } \\
\text { Component }\end{array}$ & \multicolumn{2}{|c|}{ Formal Questionnaire(Appendix A) } \\
\hline V14 & $\begin{array}{l}\text { How often are transformational project delivery } \\
\text { methods, such as EPC, BT, or BOT, used in } \\
\text { your company? }\end{array}$ & F1-2 & No. 2 & \multirow{4}{*}{$\begin{array}{l}\text { Implementation } \\
\text { level of } \\
\text { transformational } \\
\text { development }\end{array}$} \\
\hline V16 & $\begin{array}{l}\text { What is the extent of standardization in } \\
\text { your company? }\end{array}$ & F1-3 & No. 3 & \\
\hline V17 & $\begin{array}{l}\text { What is the extent of improvement of living } \\
\text { conditions of your company's construction } \\
\text { laborers? }\end{array}$ & F1-4 & No. 4 & \\
\hline V29 & $\begin{array}{l}\text { How important is brand building to your company } \\
\text { in improving its development? }\end{array}$ & F1-7 & No. 7 & \\
\hline V 15 & $\begin{array}{l}\text { How important are your company's corporate } \\
\text { earnings from EPC, BT, or BOT? }\end{array}$ & F2-1 & No. 1 & \multirow{3}{*}{$\begin{array}{l}\text { External } \\
\text { information } \\
\text { integration }\end{array}$} \\
\hline V 36 & $\begin{array}{l}\text { In your company's project management } \\
\text { services, how well is the information-related } \\
\text { budget managed? }\end{array}$ & F2-2 & No. 2 & \\
\hline V37 & $\begin{array}{l}\text { What is the extent of your company's clarity of } \\
\text { information channels and platforms used to } \\
\text { share economic and market trends (e.g., in memos, } \\
\text { company newsletters, and/or on the } \\
\text { company's website)? }\end{array}$ & $\mathrm{F} 2-3$ & No. 3 & \\
\hline
\end{tabular}


Table 3. Cont.

\begin{tabular}{|c|c|c|c|c|}
\hline \multirow{2}{*}{ Original Question No. } & \multirow[b]{2}{*}{ Item } & \multirow{2}{*}{$\begin{array}{l}\text { Principle } \\
\text { Component }\end{array}$} & \multicolumn{2}{|c|}{ Formal Questionnaire(Appendix A) } \\
\hline & & & $\begin{array}{l}\text { Final Question } \\
\text { No. }\end{array}$ & $\begin{array}{l}\text { Name of Principle } \\
\text { Component }\end{array}$ \\
\hline V22 & $\begin{array}{l}\text { How important is the implementation of quality } \\
\text { and safety standards to your company's } \\
\text { corporate managers? }\end{array}$ & F3-1 & No. 1 & \multirow{4}{*}{$\begin{array}{l}\text { Project knowledge } \\
\text { management }\end{array}$} \\
\hline V 23 & $\begin{array}{l}\text { How well is project standardization managed in } \\
\text { your company? }\end{array}$ & F3-2 & No. 2 & \\
\hline V24 & $\begin{array}{l}\text { What is your opinion of the implementation of } \\
\text { project knowledge training in your company? }\end{array}$ & F3-3 & No. 3 & \\
\hline V25 & $\begin{array}{l}\text { How familiar are you with the Excellence Project } \\
\text { Management Model published by the Ministry of } \\
\text { Housing and Urban-Rural Development of the } \\
\text { People's Republic of China (MOURD, P. R. China)? }\end{array}$ & F3-4 & No. 4 & \\
\hline V26 & $\begin{array}{l}\text { What is your opinion of your company's } \\
\text { implementation of the Excellence Project } \\
\text { Management Model published by MOURD? }\end{array}$ & F4-1 & No. 1 & \multirow{2}{*}{$\begin{array}{l}\text { Corporate brand } \\
\text { building support }\end{array}$} \\
\hline V27 & $\begin{array}{l}\text { Does your company have a brand } \\
\text { building department? }\end{array}$ & $\mathrm{F} 4-2$ & No. 2 & \\
\hline
\end{tabular}

Source: Adoption of research of Zhang et al. [21].

\subsection{Average Score Method Analysis}

\subsubsection{Growth Level Using the Average Score Method}

On the basis of Table 3 in Section 4.1, using the average score method with Equations (1) and (2) in Section 3.1, it is easy to generate the average score of the construction industry growth management of Shaanxi Province, which is 40.927. At the same time, using Table 2 in Section 3.1, we can arrive at each growth level, as shown in Table 4. Thus, it is easy to find that Shaanxi's construction industry maturity level is Level II. Analogous to the framework of GMM [20], the maturity level and whole process of Shaanxi's construction industry growth are clearly shown in Figure 4, which also indicates that its status is still at an early level. Thus it should look for ways to improve its growth.

Table 4. Growth level and scope using the average score method.

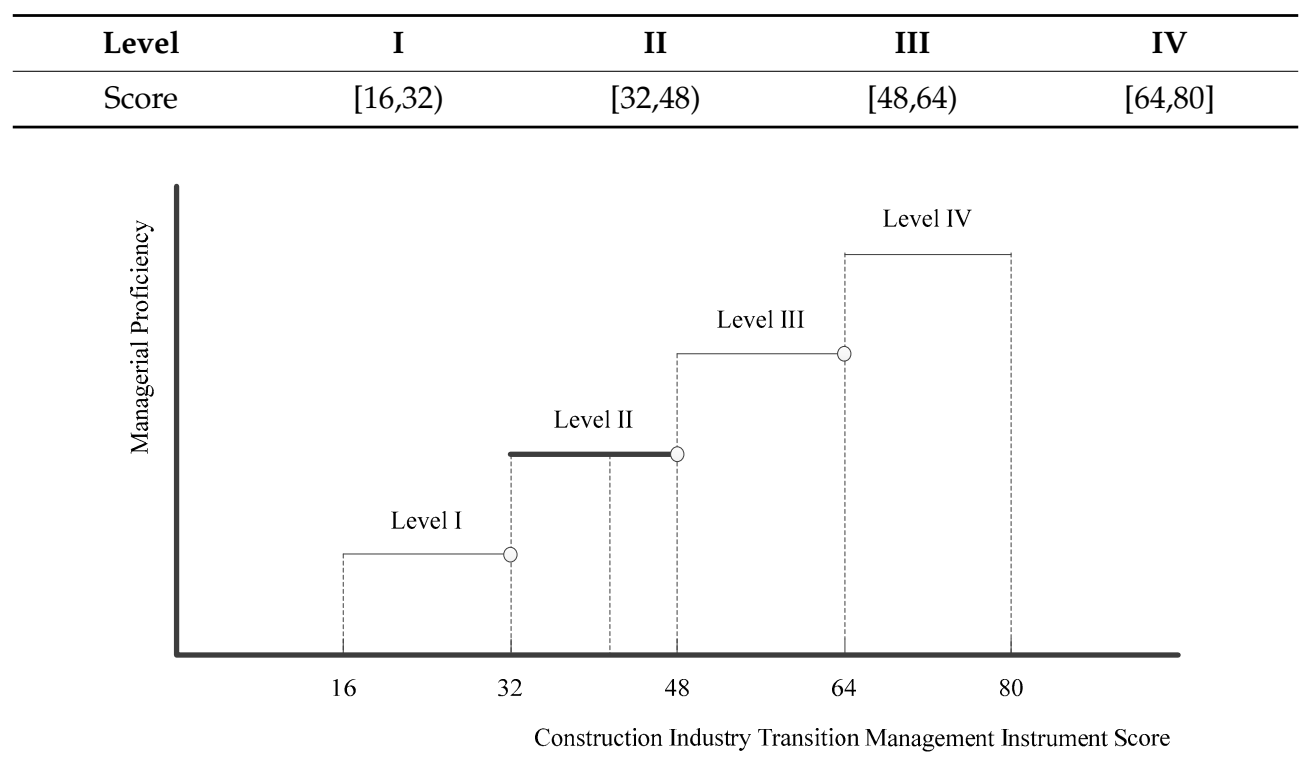

Figure 4. Level of Shaanxi's construction industry growth management using average score method with GMM framework. 


\subsubsection{Impact Factors Using the Average Score Method}

Our research uses three lower frequency percentages as threshold values to analyze the impact factor, with Equation (10) generating the degree of difficulty of each index, as shown in Table 5. According to past research $[52,54,58,69,70]$, the smaller the frequency percent of each index is, the stronger the hindering influence. In Table 5, we can see that F1-7 in Table 3 is the smallest frequency percent, which indicates that Shaanxi's construction industry's brand building support is unable to meet the requirements for transition at the present time. The values of F3-2 (59) and F3-4 (60) in Table 5 are smaller than all the other values, which shows that Shaanxi's construction industry is not standardized and needs to learn effective project management. The industry should also become familiar with the Excellence Project Management Model compiled by MOURD, China.

Table 5. Impact factors using the average score method.

\begin{tabular}{ccccccccccccccccc}
\hline Index & F1-1 & F1-2 & F2-1 & F1-3 & F1-4 & F1-5 & F-16 & F3-1 & F3-2 & F3-3 & F3-4 & F4-1 & F4-2 & F1-7 & F2-2 & F2-3 \\
\hline Frequency & 62 & 84 & 99 & 94 & 79 & 78 & 66 & 90 & 59 & 88 & 60 & 93 & 82 & 48 & 62 & 81 \\
Frequency $\%$ & 50.4 & 68.3 & 80.5 & 76.4 & 64.2 & 63.4 & 53.7 & 73.2 & 48 & 71.5 & 48.8 & 75.6 & 66.7 & 39 & 50.4 & 65.9 \\
\hline
\end{tabular}

\subsection{Entropy Method Analysis}

\subsubsection{Impact Factors Using the Entropy Method}

We used Equations (3) and (4) in Section 3.2 to standardize the data of the final questionnaire. We then applied Equations (5)-(7) in Section 3.2 to generate the entropy weight of the 16 indices in Table 3, which are shown in Table 6.

Table 6. Index entropy weight of Shaanxi construction industry.

\begin{tabular}{ccccccccccccccccc}
\hline Index & F1-1 & F1-2 & F1-3 & F1-4 & F1-5 & F1-6 & F1-7 & F2-1 & F2-2 & F2-3 & F3-1 & F3-2 & F3-3 & F3-4 & F4-1 & F4-2 \\
\hline Entropy weight & 0.061 & 0.055 & 0.065 & 0.062 & 0.056 & 0.044 & 0.043 & 0.078 & 0.050 & 0.052 & 0.043 & 0.111 & 0.114 & 0.039 & 0.062 & 0.065 \\
\hline
\end{tabular}

\subsubsection{Impact Factors Using the Entropy Method}

By calculating the Shaanxi construction industry's growth level using the entropy method of Equation (8), we generate a score of 2.55, which is at Level II. Compared with Table 2 in Section 3.2, we can then see that the level of management proficiency of the Shaanxi construction industry lies at the second level, as shown in Figure 5, which is also consistent with the results of Charles McIntyre (2015) [20].

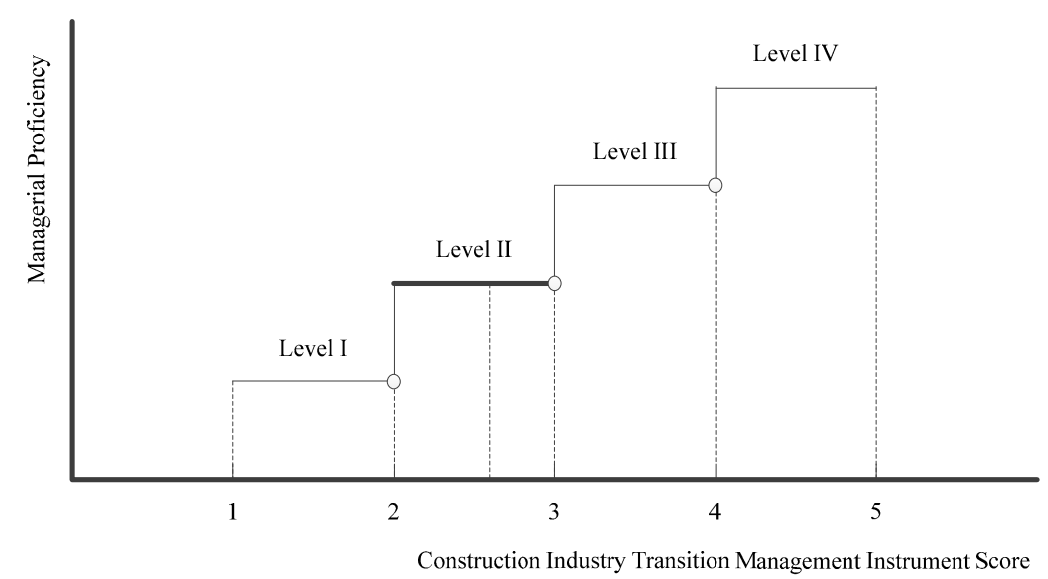

Figure 5. Level of Shaanxi's construction industry using the entropy method with GMM framework. 


\subsubsection{Impact Factors Using the Entropy Method}

Equation (9) of the barrier degree method in Section 3.3 allows us to generate the frequency percentages of the impact factors using the entropy method. The results are shown in Table 7.

Table 7. Impact factors using the entropy method.

\begin{tabular}{ccccccccccccccccc}
\hline Index & F1-1 & F1-2 & F2-1 & F1-3 & F1-4 & F-15 & F1-6 & F3-1 & F3-2 & F3-3 & F3-4 & F4-1 & F4-2 & F1-7 & F2-2 & F2-3 \\
\hline Frequency & 58 & 69 & 99 & 93 & 61 & 35 & 19 & 96 & 35 & 67 & 24 & 95 & 95 & 8 & 60 & 81 \\
Frequency $\%$ & 47.2 & 56.1 & 80.5 & 75.6 & 49.6 & 28.5 & 15.4 & 78 & 28.5 & 54.5 & 19.5 & 77.2 & 77.2 & 6.5 & 48.8 & 65.9 \\
\hline
\end{tabular}

With regard to Table 7, we can see that the three lowest frequency percentages of the indices of Table 3 are F1-7 (6.5\%), F1-6 (15.4\%), and F3-4 (19.5\%). Thus, in order to manage the growth drivers of Shaanxi's construction industry, the local government may need to pay more attention to improving the maturity level of this industry. This may be done by project management systems implementation, brand building, and project knowledge management, as well as enhancing the understanding of the Excellence Project Management Model compiled by MOURD, China.

\subsection{Discussion}

The above research shows that brand building is the most important factor needed to drive up Shaanxi's construction industry. Standardization, knowledge management through lessons learned, and cost management for budget control by using information systems are required for construction project management. Understanding of the Excellent Project Management Model of China is a trend for Chinese project knowledge management.

Technological innovation, information systems, urban and rural infrastructure, and knowledge management and training in the construction industry are the most important potential areas to enhance in order to drive up growth $[19,25,27,42,71,72]$. The results of our research show that the Shaanxi construction industry is on the second level of managerial proficiency and also that the critical impact factors of future growth are the driving forces of transformation and project knowledge management in this industry. Our research also prioritizes the factors of organizational growth.

This research summarizes the top seven impact factors as shown in Table 8 . Other researchers $[23,24,73,74]$ recommend that the local government stimulate the transformation of construction enterprises and encourage these businesses to focus on implementing innovative business models such as service-driven engineering, procurement, construction, and partnering. In Table 8, the results from the entropy method are more consistent with still other research $[34,50,52,55,75]$. Questions such as "How significant is the attention given to propagating the lessons learned from successful projects in your company?" (F1-1 in Table 3), "At what level is the implementation of project information management in your company?" (F1-5 in Table 3), and "How well is project standardization managed in your company?" (F3-2 in Table 3) should be the significant impact factors for Shaanxi construction industry growth management.

Table 8. Top seven impact factors by using the entropy method and the average score method.

\begin{tabular}{ccccc}
\hline \multirow{2}{*}{ Rank } & \multicolumn{2}{c}{ Average Score Method } & \multicolumn{2}{c}{ Entropy Method } \\
\cline { 2 - 5 } & Impact Factor & Frequency $\%$ & Impact Factor & Frequency \% \\
\hline $\mathbf{1}$ & F1-7 & 39 & F1-7 & 6.5 \\
$\mathbf{2}$ & F3-2 & 48 & F1-6 & 15.4 \\
$\mathbf{3}$ & F3-4 & 48.8 & F3-4 & 19.5 \\
$\mathbf{4}$ & F1-1 & 50.4 & F1-5 & 28.5 \\
$\mathbf{5}$ & F2-2 & 50.4 & F3-2 & 28.5 \\
$\mathbf{6}$ & F1-6 & 53.7 & F1-1 & 47.2 \\
$\mathbf{7}$ & F1-5 & 63.4 & F2-2 & 48.8 \\
\hline
\end{tabular}


Additionally, using the growth driver aspect as shown in Table 9, the different methods give us almost consistent results for the impact factors. Researchers $[23,24,73,74,76,77]$ further suggest the importance of talent training and technological innovation. Our research focuses on the maturity analysis of the construction industry and its impact factors needed for the companies. For example, in order to update the managerial proficiency level of the construction industry, the local government should encourage the industry to pay attention to brand building in order to enhance brand recognition in the market. This result is consistent with the central tenets of "Rethinking Construction: the Egan Report", which mentions the importance of learning strategies and methods in construction industry management and enhancing the application of brand strategy performance tools and techniques [78].

Table 9. Impact factors of the growth driver aspect using the entropy method and the average score method.

\begin{tabular}{ccc}
\hline Growth Driver & Method & Impact Factor \\
\hline Implementation level of & Average score method & F1-7 \\
transformational development & Entropy method & F1-7 \\
\hline \multirow{2}{*}{ External information integration } & Average score method & F2-2 \\
& Entropy method & F2-2 \\
\hline \multirow{2}{*}{ Project knowledge management } & Average score method & F3-2 \\
& Entropy method & F3-4 \\
\hline \multirow{2}{*}{ Corporate brand building support } & Average score method & F4-2 \\
& Entropy method & F4-1, F4-2 \\
\hline
\end{tabular}

\section{Conclusions}

This research reviews the characteristics of Shaanxi Province's construction industry, defines its growth drivers, and develops a growth management model (GMM). The research investigates the maturity levels of the construction industry in Shaanxi, which is on its national government's pilot list. This study also researches Shaanxi's significant impact factors on its industry level and explains the four growth drivers and 16 corresponding indicators of growth management in this province. The empirical research shows that the growth management of Shaanxi's construction industry lies on the second of four maturity levels. This indicates that the construction industry of Shaanxi is at an early stage of growth management and is facing some critical problems, such as a low level of transformation and a lack of project knowledge management. The Shaanxi construction industry may need to enhance the brand building in its enterprises' developmental strategies, to increase budgets on training as well as research and development, and to implement project standardization management.

This research proposes a theoretical framework for analyzing the maturity status of a developing industry. The results of this research can help policymakers, leaders, and managers understand the maturity status of their industries and develop their own strategies for economic sustainability. The research has adopted the barrier degree method to analyze the impact factors in the corresponding transition steps. Empirical research shows that the entropy method can more clearly target potential barriers than the average score method when assessing the accountability of an ecosystem in its developing construction industry. These research results can provide a good foundation for improving the transition process of construction industry management. The application of the results of this research to the development of maturity growth management may be particularly useful in similar industries of other developing countries which may need improvement in their own approaches to managing economic sustainability.

Acknowledgments: This research is supported by the National Natural Science Foundation of China (No. 71301013); Humanity and Social Science Program Foundation of the Ministry of Education of China (No. 13YJA790150); China ASC Fund (No. asc-kt2014022 and No. asc-kt2014023); China Scholarship Council; Shaanxi Nature Science Fund (No. 2014JM2-7140); Shaanxi Social Science Fund (No. 2016ZB017, No. 2014HQ10, No. 2015Z071, No. $2015 Z 075$ and No. 2016Z047); Xi' an Science Technology Bureau Fund(No. CXY1512[2]); Special 
Fund for Graduate Student Education Reform of Central College, Chang'an University (No. jgy16062); Special Fund for Basic Scientific Research of Central College (Humanities and Social Sciences), Chang'an University (No. 0009-2014G6285048, No. 310828155031, No. 310828160661, and No. 310828160663). Thanks to Anne Reifler for proofreading this paper.

Author Contributions: Jingxiao Zhang and Hui Li conducted the interviews, analyzed the data, and contributed to drafting the paper. Jingxiao Zhang and Hui Li contributed to the concept and design of the paper. Steve Hsueh-Ming Wang developed the cycle of APBP for economic sustainability analysis and edited its final version. Jingxiao Zhang was in charge of the final submission.

Conflicts of Interest: The authors declare no conflict of interest.

\section{Abbreviations}

GMM Growth management model

MOURD, P. R. China Ministry of Housing and Urban-Rural Development of the People's Republic of China

IAB Industry Advisory Board

\section{Appendix A. Original Questionnaire}

Questionnaire Survey for Power Factors and Transformational Mechanism in Construction Companies in Shaanxi Province, China

Survey Explanation: The purpose of the survey to determine the types, characteristics, and development issues of construction companies during transformation. The data collected will only be used for research and policy-making support. Your ID information will be kept confidential.

\section{Part One: Background (Choose 1 answer for each question.)}

1. Your employer is a(an):

(1). University; (2). Supervision Company; (3). Owner; (4). Design Company;

(5). Construction company; (6). Bidding Service Company; (7). Government;

(8). Consultancy Company; (9). Inspection Service; (10). Other:

2. Your final education is:

(1). Vocational;

(2). Associate Degree;

(3). Bachelor Degree;

(4). Master's Degree;

(5). Ph.D. Degree

3. Your work experience is:

(1). $\leq 5$ years;

(2). 6-10 years;

(3). 11-15 years;

(4). 16-20 years;

(5). $\geq 21$ years

4. If you work for a construction company, your company size is:

(1). Large-scale, state-owned;

(2). Large-scale, private;

(3). Small-and-medium, state-owned;

(4). Small-and-medium private

5. Your job responsibility is at which of the following category? A; B; C; D and others.

(1). Entry level;

(2). Intermediate;

(3). Administrative;

(4). Other

Part Two: Power factors and indicators for transformational development of construction enterprises

6. What is/are your company's main scope(s) of business (Limit to 4 selections)? 
(1). Real estate; (2). Residential construction; (3). R \& D; (4). Design

(5). Supervision; (6). Engineering consulting; (7). Capital management and investment

(8). Municipal construction; (9). Roads \& bridges construction

(10). Industrial plants and parks; (11). Interior finishes

(12). Overseas business development; (13). Prefabricated building

(14). Material supplier; (15). CM service; (16). Steel structure

7. Does your company have other business (Limit to 4 selections)?

(1). Real estate; (2). Residential construction; (3). R \& D; (4). Design

(5). Supervision; (6). Engineering consulting; (7). Capital management and investment

(8). Municipal construction; (9). Roads \& bridges construction

(10). Industrial plants and parks; (11). Interior finishes

(12). Overseas business development; (13). Prefabricated building (NPC)

(14). Material supplier; (15). CM service; (16). Steel structure

8. In your opinion, would the business of your company transform into the following areas? (Limit to 4 selections)

(1). Real estate; (2). Residential construction; (3). R \& D; (4). Design

(5). Supervision; (6). Engineering consulting; (7). Capital management and investment

(8). Municipal construction; (9). Roads \& bridges construction

(10). Industrial plants and parks; (11). Interior finishes

(12). Overseas business development; (13). Prefabricated building (NPC)

(14). Material supplier; (15). CM service; (16). Steel structure

9. Does your company pay attention in summarizing the advanced methods used in excellent projects?
A. Very significant, having designated manager
B. Some significant, having a part-time manager
C. Significant, having a designated person
D. Somewhat insignificant
E. Very insignificant

10. How well do you know about the incentive extent of project marketing by a special team?
A. Very well;
B. Relatively well;
C. Well;
D. Not very well;
E. Do not know

11. How significant is the attention given in propagating the advanced practice gained through successful projects in your company?
A. Very significant, having designated manager
B. Some significant, having a part-time manager
C. Significant, having a designated person
D. Somewhat insignificant
E. Very insignificant

12. To what level is the influence of the "10 New Technologies in the Construction Industry" to your company's $\mathrm{R} \& \mathrm{D}$ ?
A. Very significant;
B. Some significant;
C. Significant;
D. Somewhat insignificant
E. Very insignificant

13. How strict does your company enforce the environmental friendly activities of site management (such as noise control, centralized collection of construction waste, and dust control)?
A. Very strict implementation, having designated person to inspect every day
B. Strict implementation, having frequent and regular inspection
C. General implementation, having frequent and random inspection 
D. Somewhat not strict, having random inspection

E. Not strict

14. How often are transformational project delivery methods, such as EPC, BT or BOT, used?
A. Very often;
B. Somewhat often;
C. Neutral;
D. Somewhat not often;
E. Never

15. How important are the corporate earnings from EPC, BT or BOT?
A. Very important
B. Important
C. Somewhat important
D. Not very important
E. Not important

16. What is the extent of standardization in enterprise management?
A. Excellent
B. Good
C. Average
D. Poor
E. Very Poor

17. What is the extent of improvement for living conditions for construction laborers?
A. Excellent
B. Good
C. Average
D. Poor
E. Very Poor

18. At what level is the implementation of project information management?
A. Excellent
B. Good
C. Average
D. Poor
E. Very Poor

19. How prevalent are joint venture and equity used in the project management system?
A. Very high
B. High
C. Moderate
D. Low
E. Very Low

20. In your opinion, what is the level of improvement in the training and use of migrant workers in the construction industry, in the aspects of using contract, standardization, and normalization?
A. Very significant;
B. Some significant;
C. Significant;
D. Somewhat insignificant;
E. Very insignificant

21. What is the implementation extent of skill training for employees in your company?
A. Very significant;
B. Some significant;
C. Significant; 
D. Somewhat insignificant;

E. Very insignificant

22. How important is the implementation of quality and safety standards to the corporate's managers?
A. Very important
B. Important
C. Somewhat important
D. Not very important
E. Not important

23. How well is project standardization managed in your company?
A. Excellent
B. Good
C. Average
D. Poor
E. Very Poor

24. What is your opinion of the implementation of project knowledge training in your company?
A. Excellent
B. Good
C. Average
D. Poor
E. Very Poor

25. How familiar are you with the Excellence Project Management Model guided by Ministry of Housing and Urban-Rural Development of the People's Republic of China (MOURD, P. R. China)?
A. Very familiar
B. Familiar
C. Acceptable familiar
D. Not very familiar
E. Hardly ever heard

26. What is your opinion of the implementation of the Excellence Project Management Model Guided by MOURD in your company?
A. Very well
B. Well
C. Adequately
D. Poorly
E. Very poorly

27. Does your company have a brand-building department?
A. Yes. There is a designated unit.
B. Yes. There is a shared (part time) unit.
C. No. We don't have it.

28. Does your company have a brand-building manager?
A. Yes. There is a designated high-rank manager.
B. Yes. There is a designated production manager.
C. No. We don't have a designated high-rank manager.
D. No. We don't have a designated production manager.

29. How important is brand-building in the future to improve the enterprise's development?
A. Very important
B. Important
C. Somewhat important
D. Not very important
E. Not important 
30. How important was brand-building in the history of the enterprise's development?
A. Very important
B. Important
C. Somewhat important
D. Not very important
E. Not important

31. In recent years, the highest investment of the brand-building is:
A. R \& D investment;
B. Production equipment;
C. Advertising;
D. Sales channels;
E. Other.

32. The most competitive factor of brand building is:
A. The ability to innovate;
B. Product quality;
C. Service level;
D. Brand Culture;
E. marketing;
F. Other

33. The most important way to corporate branding is:
A. Television advertising;
B. Newspaper Advertising;
C. Outdoor advertising;
D. Public relations activities;
E. online advertising;
F. Industry Award;
G. Exhibition.

34. Does your company have the intent of mergers or setup new regional offices in other provinces (except local province)?
A. Very clear intention;
B. Relative clear intention;
C. General clear intention;
D. Not very clear intention;
E. No intention;
F. Do not know

35. Does your company have the plan of entering emerging industrial areas (such as non-building market)?
A. Very clear intention;
B. Relative clear intention;
C. In the process of making such a plan;
D. No intention;
E. May consider this in the future

36. In your company's project management services, how well is the information-related budget managed?
A. Excellent
B. Good
C. Average
D. Poor
E. Very Poor

37. What is the extent of the clarity of information channels and platforms to share the economic and market trends (e.g., in memos, company newsletters, or on the company's website)?
A. Excellent
B. Good 


\section{Average \\ D. Poor \\ E. Very Poor}

38. How significant is the self-improvement training of corporate manager on corporate business?

(1). very significant;

(2). some significant;

(3). significant;

(4). somewhat insignificant

(5). very insignificant

39. The funding solutions of your company's project management services mainly rely on (limit to 3 multiple choices):

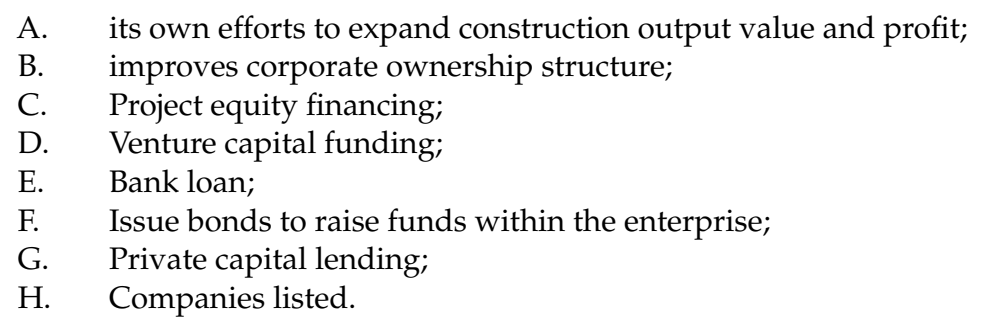

40. How much effort does Shaanxi Province put on the protection of the local construction market?

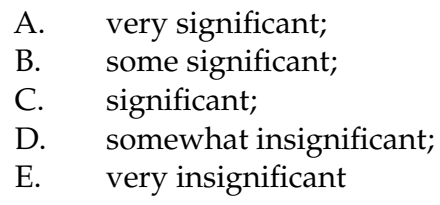

41. How strict is the implementation extent of corporate audit and quality control for procurement contracts?
A. Very strict implementation, having designated department and manager
B. Strict implementation, having part-time department and manager
C. General implementation, having designated person
D. Somewhat not strict, having part-time person
E. Not strict

\section{Appendix B. Formal Questionnaire of Transformational Development for Construction Enterprises}

The purpose of the survey you are being asked to complete is to determine the types, characteristics, and development issues of construction companies in the transformation period. This objective of this survey focused on the specific transformation analysis on the enterprise power factors, driving force and types of construction enterprises. You can give up the response at your will.

- $\quad$ First part: Background (choose one item)

1. Your employer: A high university, B supervision company, C owner, D design company, E construction company, $\mathrm{F}$ bidding company, $\mathrm{G}$ government, $\mathrm{H}$ consultancy company.

2. Your education accepted: A Technical school, B college, C graduate, D others.

3. Your work experience: A less than 5 years, B 6-10 years, C 11-15 years, D 16-20 years, E more than 21 years.

4. Your company size: A large-scale state-owned construction enterprise, B large-scale private construction companies, C small-and-medium state-owned construction companies, D small-and-medium private construction enterprises.

5. Your job title: A entry-level, B intermediate, $C$ advanced, D others.

- Second part: Driving force and its indicator for transformational development of construction enterprise

Questions about Implementation level of transformational development (F1):

1. How significant is the attention given in propagating the advanced practice gained through successful projects in your company? 

a. Very significant, having designated manager
b. Some significant, having a part-time manager
c. Significant, having a designated person
d. Somewhat insignificant
e. Very insignificant

2. How often are transformational project delivery methods, such as EPC, BT or BOT, used?
a. Very often
b. Somewhat often
c. Neutral
d. Somewhat not often
e. Never

3. What is the extent of standardization in enterprise management?
a. Excellent
b. Good
c. Average
d. Poor
e. Very Poor

4. What is the extent of improvement for living conditions for construction laborers?
a. Excellent
b. Good
c. Average
d. Poor
e. Very Poor

5. At what level is the implementation of project information management?
a. Excellent
b. Good
c. Average
d. Poor
e. Very Poor

6. How prevalent are joint venture and equity used in the project management system?
a. Very high
b. High
c. Moderate
d. Low
e. Very Low

7. How important is brand-building in the future to improve the enterprise's development?
a. Very important
b. Important
c. Somewhat important
d. Not very important
e. Not important

Questions about External Information Integration (F2):

1. How important are the corporate earnings from EPC, BT or BOT?
a. Very important
b. Important
c. Somewhat important
d. Not very important
e. Not important

2. In your company's project management services, how well is the information-related budget managed?
a. Excellent
b. Good 

c. Average
d. Poor
e. Very Poor

3. What is the extent of the clarity of information channels and platforms to share the economic and market trends (e.g., in memos, company newsletters, or on the company's website)?
a. Excellent
b. Good
c. Average
d. Poor
e. Very Poor

Questions about Project Knowledge Management (F3):

1. How important is the implementation of quality and safety standards to the corporate's managers?
a. Very important
b. Important
c. Somewhat important
d. Not very important
e. Not important

2. How well is project standardization managed in your company?
a. Excellent
b. Good
c. Average
d. Poor
e. Very Poor

3. What is your opinion of the implementation of project knowledge training in your company?
a. Excellent
b. Good
c. Average
d. Poor
e. Very Poor

4. How familiar are you with the Excellence Project Management Model guided by Ministry of Housing and Urban-Rural Development of the People's Republic of China (MOURD, P. R. China)?
a. Very familiar
b. Familiar
c. Acceptable familiar
d. Not very familiar
e. Hardly ever heard

Questions about corporate brand building (F4):

1. What is your opinion of the implementation of the Excellence Project Management Model Guided by MOURD in your company?
a. Very well
b. Well
c. Adequately
d. Poorly
e. Very poorly

2. Does your company have a brand-building department?
a. Yes. There is a designated unit.
b. Yes. There is a shared (part time) unit.
c. No. We don't have it 
Appendix C.

Table C1. The Descriptive Statistics of Original Questionnaire.

\begin{tabular}{|c|c|c|c|c|c|c|c|c|c|c|c|c|}
\hline \multirow{2}{*}{ Question Code } & \multirow{2}{*}{$\frac{\mathrm{N}}{\text { Statistic }}$} & \multirow{2}{*}{$\begin{array}{l}\text { Range } \\
\text { Statistic }\end{array}$} & \multirow{2}{*}{$\begin{array}{c}\text { Minimum } \\
\text { Statistic }\end{array}$} & \multirow{2}{*}{$\begin{array}{c}\text { Maximum } \\
\text { Statistic }\end{array}$} & \multicolumn{2}{|c|}{ Mean } & \multirow{2}{*}{$\begin{array}{c}\text { Std. Deviation } \\
\text { Statistic }\end{array}$} & \multirow{2}{*}{$\begin{array}{l}\text { Variance } \\
\text { Statistic }\end{array}$} & \multicolumn{2}{|c|}{ Skewness } & \multicolumn{2}{|c|}{ Kurtosis } \\
\hline & & & & & Statistic & Std. Error & & & Statistic & Std. Error & Statistic & Std. Error \\
\hline V6 & 123 & 18 & 1 & 19 & 4.24 & 0.339 & 3.755 & 14.100 & 1.919 & 0.218 & 3.773 & 0.433 \\
\hline V7 & 123 & 18 & 1 & 19 & 5.66 & 0.379 & 4.202 & 17.653 & 1.173 & 0.218 & 0.793 & 0.433 \\
\hline V8 & 123 & 17 & 1 & 18 & 4.50 & 0.358 & 3.968 & 15.744 & 1.753 & 0.218 & 2.529 & 0.433 \\
\hline V9 & 123 & 4 & 1 & 5 & 2.03 & 0.099 & 1.093 & 1.196 & 1.197 & 0.218 & 1.048 & 0.433 \\
\hline V10 & 123 & 4 & 1 & 5 & 2.20 & 0.106 & 1.173 & 1.376 & 0.834 & 0.218 & -0.022 & 0.433 \\
\hline V11 & 123 & 4 & 1 & 5 & 2.37 & 0.090 & 0.995 & 0.990 & 0.508 & 0.218 & -0.402 & 0.433 \\
\hline V12 & 123 & 4 & 1 & 5 & 2.19 & 0.079 & 0.881 & 0.776 & 0.500 & 0.218 & 0.015 & 0.433 \\
\hline V13 & 123 & 4 & 1 & 5 & 2.48 & 0.079 & 0.872 & 0.760 & 0.101 & 0.218 & -0.285 & 0.433 \\
\hline V14 & 123 & 4 & 1 & 5 & 2.76 & 0.091 & 1.011 & 1.022 & 0.266 & 0.218 & -0.806 & 0.433 \\
\hline V15 & 123 & 4 & 1 & 5 & 3.08 & 0.104 & 1.149 & 1.321 & -0.030 & 0.218 & -1.115 & 0.433 \\
\hline V16 & 122 & 4 & 1 & 5 & 2.98 & 0.100 & 1.102 & 1.214 & -0.139 & 0.219 & -1.024 & 0.435 \\
\hline V17 & 123 & 4 & 1 & 5 & 2.60 & 0.089 & 0.990 & 0.979 & 0.254 & 0.218 & -0.299 & 0.433 \\
\hline V18 & 123 & 4 & 1 & 5 & 2.60 & 0.080 & 0.885 & 0.783 & 0.444 & 0.218 & 0.070 & 0.433 \\
\hline V19 & 123 & 4 & 1 & 5 & 2.46 & 0.076 & 0.842 & 0.710 & 0.284 & 0.218 & -0.101 & 0.433 \\
\hline V20 & 123 & 4 & 1 & 5 & 2.50 & 0.080 & 0.891 & 0.793 & 0.331 & 0.218 & -0.048 & 0.433 \\
\hline V21 & 123 & 4 & 1 & 5 & 2.06 & 0.080 & 0.890 & 0.792 & 0.597 & 0.218 & 0.051 & 0.433 \\
\hline V22 & 123 & 3 & 1 & 4 & 2.40 & 0.082 & 0.912 & 0.832 & 0.043 & 0.218 & -0.798 & 0.433 \\
\hline V23 & 123 & 4 & 1 & 5 & 2.36 & 0.081 & 0.897 & 0.805 & 0.403 & 0.218 & 0.091 & 0.433 \\
\hline V24 & 123 & 4 & 1 & 5 & 2.76 & 0.087 & 0.970 & 0.940 & 0.016 & 0.218 & -0.520 & 0.433 \\
\hline V25 & 123 & 4 & 1 & 5 & 2.41 & 0.077 & 0.849 & 0.720 & 0.722 & 0.218 & 0.892 & 0.433 \\
\hline V26 & 123 & 2 & 1 & 3 & 2.15 & 0.069 & 0.765 & 0.585 & -0.255 & 0.218 & -1.243 & 0.433 \\
\hline V27 & 123 & 3 & 1 & 4 & 2.50 & 0.102 & 1.126 & 1.268 & 0.115 & 0.218 & -1.373 & 0.433 \\
\hline V28 & 123 & 4 & 1 & 5 & 2.01 & 0.069 & 0.763 & 0.582 & 0.887 & 0.218 & 1.742 & 0.433 \\
\hline V29 & 123 & 4 & 1 & 5 & 2.17 & 0.070 & 0.776 & 0.602 & 0.871 & 0.218 & 1.365 & 0.433 \\
\hline V30 & 123 & 4 & 1 & 5 & 2.64 & 0.118 & 1.307 & 1.707 & 0.669 & 0.218 & -0.610 & 0.433 \\
\hline V31 & 123 & 5 & 1 & 6 & 2.37 & 0.091 & 1.011 & 1.023 & 0.979 & 0.218 & 1.146 & 0.433 \\
\hline V32 & 123 & 6 & 1 & 7 & 4.02 & 0.174 & 1.929 & 3.721 & -0.002 & 0.218 & -1.353 & 0.433 \\
\hline V33 & 123 & 5 & 1 & 6 & 2.84 & 0.125 & 1.381 & 1.908 & 0.658 & 0.218 & -0.326 & 0.433 \\
\hline V34 & 123 & 4 & 1 & 5 & 2.72 & 0.106 & 1.177 & 1.386 & 0.328 & 0.218 & -0.810 & 0.433 \\
\hline V35 & 123 & 7 & 1 & 8 & 2.25 & 0.158 & 1.749 & 3.059 & 1.465 & 0.218 & 1.450 & 0.433 \\
\hline V36 & 123 & 4 & 1 & 5 & 2.52 & 0.094 & 1.043 & 1.088 & 0.805 & 0.218 & 0.167 & 0.433 \\
\hline V37 & 123 & 4 & 1 & 5 & 2.82 & 0.099 & 1.102 & 1.214 & -0.012 & 0.218 & -1.099 & 0.433 \\
\hline V38 & 123 & 4 & 1 & 5 & 2.62 & 0.087 & 0.963 & 0.927 & 1.172 & 0.218 & 1.068 & 0.433 \\
\hline V39 & 123 & 4 & 1 & 5 & 2.23 & 0.092 & 1.023 & 1.046 & 1.257 & 0.218 & 1.512 & 0.433 \\
\hline V40 & 123 & 4 & 1 & 5 & 2.12 & 0.089 & 0.988 & 0.977 & 1.305 & 0.218 & 1.803 & 0.433 \\
\hline V41 & 122 & 3 & 1 & 4 & 2.07 & 0.073 & 0.810 & 0.657 & 0.447 & 0.219 & -0.207 & 0.435 \\
\hline Valid N (list wise) & 121 & & & & & & & & & & & \\
\hline
\end{tabular}




\section{Appendix D.}

Table D1. Independent Samples Test of Original Questionnaire.

\begin{tabular}{|c|c|c|c|c|c|c|c|c|c|c|}
\hline & \multirow{3}{*}{ Question Code } & \multicolumn{2}{|c|}{$\begin{array}{c}\text { Levene's Test for Equality } \\
\text { of Variances }\end{array}$} & \multicolumn{7}{|c|}{$t$-Test for Equality of Means } \\
\hline & & \multirow[t]{2}{*}{$\mathbf{F}$} & \multirow[t]{2}{*}{ Sig. } & \multirow[t]{2}{*}{$\mathbf{t}$} & \multirow[t]{2}{*}{ df } & \multirow{2}{*}{$\begin{array}{c}\text { Sig. } \\
\text { (2-Tailed) }\end{array}$} & \multirow{2}{*}{$\begin{array}{c}\text { Mean } \\
\text { Difference }\end{array}$} & \multirow{2}{*}{$\begin{array}{l}\text { Std. Error } \\
\text { Difference }\end{array}$} & \multicolumn{2}{|c|}{$\begin{array}{l}\text { 95\% Confidence Interval of } \\
\text { the Difference }\end{array}$} \\
\hline & & & & & & & & & Lower & Upper \\
\hline \multirow{2}{*}{ V6 } & Equal variances assumed (EV) & 7.218 & 0.009 & 2.757 & 65 & 0.008 & 2.619 & 0.950 & 0.722 & 4.517 \\
\hline & Equal variances not assumed (NEV) & & & 2.733 & 46.996 & 0.009 & 2.619 & 0.959 & 0.691 & 4.548 \\
\hline \multirow{2}{*}{ V7 } & EV & 18.196 & 0.000 & 4.460 & 65 & 0.000 & 4.420 & 0.991 & 2.441 & 6.399 \\
\hline & NEV & & & 4.424 & 48.969 & 0.000 & 4.420 & 0.999 & 2.412 & 6.428 \\
\hline \multirow{2}{*}{ V8 } & EV & 13.430 & 0.000 & 2.838 & 65 & 0.006 & 2.644 & 0.932 & 0.783 & 4.506 \\
\hline & NEV & & & 2.807 & 41.794 & 0.008 & 2.644 & 0.942 & 0.743 & 4.546 \\
\hline \multirow[b]{2}{*}{ V9 } & EV & 19.328 & 0.000 & 4.739 & 65 & 0.000 & 1.290 & 0.272 & 0.746 & 1.833 \\
\hline & NEV & & & 4.692 & 44.608 & 0.000 & 1.290 & 0.275 & 0.736 & 1.843 \\
\hline \multirow{2}{*}{ V10 } & EV & 19.420 & 0.000 & 5.330 & 65 & 0.000 & 1.474 & 0.277 & 0.922 & 2.027 \\
\hline & NEV & & & 5.283 & 47.422 & 0.000 & 1.474 & 0.279 & 0.913 & 2.035 \\
\hline \multirow{2}{*}{ V11 } & EV & 12.673 & 0.001 & 8.448 & 65 & 0.000 & 1.626 & 0.192 & 1.241 & 2.010 \\
\hline & NEV & & & 8.381 & 49.783 & 0.000 & 1.626 & 0.194 & 1.236 & 2.015 \\
\hline \multirow{2}{*}{ V12 } & EV & 0.050 & 0.824 & 4.758 & 65 & 0.000 & 0.961 & 0.202 & 0.557 & 1.364 \\
\hline & NEV & & & 4.753 & 64.396 & 0.000 & 0.961 & 0.202 & 0.557 & 1.365 \\
\hline \multirow[b]{2}{*}{ V13 } & EV & 0.573 & 0.452 & 4.908 & 65 & 0.000 & 0.939 & 0.191 & 0.557 & 1.322 \\
\hline & NEV & & & 4.900 & 63.705 & 0.000 & 0.939 & 0.192 & 0.556 & 1.322 \\
\hline \multirow{2}{*}{ V14 } & EV & 4.505 & 0.038 & 9.777 & 65 & 0.000 & 1.726 & 0.177 & 1.374 & 2.079 \\
\hline & NEV & & & 9.740 & 60.290 & 0.000 & 1.726 & 0.177 & 1.372 & 2.081 \\
\hline \multirow{2}{*}{ V15 } & EV & 0.020 & 0.888 & 8.471 & 65 & 0.000 & 1.761 & 0.208 & 1.346 & 2.176 \\
\hline & NEV & & & 8.459 & 63.918 & 0.000 & 1.761 & 0.208 & 1.345 & 2.177 \\
\hline \multirow{2}{*}{ V16 } & EV & 0.497 & 0.483 & 9.658 & 64 & 0.000 & 1.758 & 0.182 & 1.394 & 2.121 \\
\hline & NEV & & & 9.658 & 61.872 & 0.000 & 1.758 & 0.182 & 1.394 & 2.121 \\
\hline \multirow[b]{2}{*}{ V17 } & EV & 2.462 & 0.122 & 6.538 & 65 & 0.000 & 1.449 & 0.222 & 1.006 & 1.892 \\
\hline & NEV & & & 6.507 & 58.454 & 0.000 & 1.449 & 0.223 & 1.003 & 1.895 \\
\hline \multirow{2}{*}{ V18 } & EV & 6.791 & 0.011 & 5.483 & 65 & 0.000 & 1.121 & 0.204 & 0.713 & 1.530 \\
\hline & NEV & & & 5.450 & 55.025 & 0.000 & 1.121 & 0.206 & 0.709 & 1.533 \\
\hline
\end{tabular}


Table D1. Cont.

\begin{tabular}{|c|c|c|c|c|c|c|c|c|c|c|}
\hline & \multirow{3}{*}{ Question Code } & \multicolumn{2}{|c|}{$\begin{array}{c}\text { Levene's Test for Equality } \\
\text { of Variances }\end{array}$} & \multicolumn{7}{|c|}{$t$-Test for Equality of Means } \\
\hline & & \multirow[t]{2}{*}{$\mathbf{F}$} & \multirow[t]{2}{*}{ Sig. } & \multirow[t]{2}{*}{$\mathbf{t}$} & \multirow[t]{2}{*}{ df } & \multirow{2}{*}{$\begin{array}{c}\text { Sig. } \\
\text { (2-Tailed) }\end{array}$} & \multirow{2}{*}{$\begin{array}{c}\text { Mean } \\
\text { Difference }\end{array}$} & \multirow{2}{*}{$\begin{array}{l}\text { Std. Error } \\
\text { Difference }\end{array}$} & \multicolumn{2}{|c|}{$\begin{array}{c}95 \% \text { Confidence Interval of } \\
\text { the Difference }\end{array}$} \\
\hline & & & & & & & & & Lower & Upper \\
\hline \multirow{2}{*}{ V19 } & EV & 2.370 & 0.129 & 7.045 & 65 & 0.000 & 1.210 & 0.172 & 0.867 & 1.553 \\
\hline & NEV & & & 7.016 & 59.511 & 0.000 & 1.210 & 0.173 & 0.865 & 1.555 \\
\hline \multirow[b]{2}{*}{ V20 } & EV & 1.704 & 0.196 & 5.480 & 65 & 0.000 & 1.032 & 0.188 & 0.656 & 1.408 \\
\hline & NEV & & & 5.456 & 58.825 & 0.000 & 1.032 & 0.189 & 0.654 & 1.411 \\
\hline \multirow{2}{*}{ V21 } & EV & 1.394 & 0.242 & 4.833 & 65 & 0.000 & 0.956 & 0.198 & 0.561 & 1.352 \\
\hline & NEV & & & 4.815 & 60.423 & 0.000 & 0.956 & 0.199 & 0.559 & 1.354 \\
\hline \multirow{2}{*}{$\mathrm{V} 22$} & EV & 0.016 & 0.901 & 6.999 & 65 & 0.000 & 1.328 & 0.190 & 0.949 & 1.707 \\
\hline & NEV & & & 6.994 & 64.598 & 0.000 & 1.328 & 0.190 & 0.949 & 1.707 \\
\hline \multirow{2}{*}{ V23 } & EV & 0.790 & 0.377 & 6.871 & 65 & 0.000 & 1.325 & 0.193 & 0.940 & 1.711 \\
\hline & NEV & & & 6.831 & 55.332 & 0.000 & 1.325 & 0.194 & 0.937 & 1.714 \\
\hline \multirow{2}{*}{ V24 } & EV & 4.017 & 0.049 & 7.542 & 65 & 0.000 & 1.367 & 0.181 & 1.005 & 1.729 \\
\hline & NEV & & & 7.512 & 60.044 & 0.000 & 1.367 & 0.182 & 1.003 & 1.731 \\
\hline \multirow[b]{2}{*}{ V25 } & EV & 5.662 & 0.020 & 7.167 & 65 & 0.000 & 1.179 & 0.165 & 0.851 & 1.508 \\
\hline & NEV & & & 7.107 & 48.669 & 0.000 & 1.179 & 0.166 & 0.846 & 1.513 \\
\hline \multirow{2}{*}{ V26 } & EV & 5.886 & 0.018 & 7.079 & 65 & 0.000 & 1.051 & 0.148 & 0.754 & 1.347 \\
\hline & NEV & & & 7.108 & 61.345 & 0.000 & 1.051 & 0.148 & 0.755 & 1.346 \\
\hline \multirow{2}{*}{ V27 } & EV & 0.292 & 0.591 & 8.394 & 65 & 0.000 & 1.749 & 0.208 & 1.333 & 2.165 \\
\hline & NEV & & & 8.378 & 63.500 & 0.000 & 1.749 & 0.209 & 1.332 & 2.166 \\
\hline \multirow{2}{*}{ V28 } & EV & 1.829 & 0.181 & 3.912 & 65 & 0.000 & 0.719 & 0.184 & 0.352 & 1.086 \\
\hline & NEV & & & 3.899 & 61.182 & 0.000 & 0.719 & 0.184 & 0.350 & 1.088 \\
\hline \multirow[b]{2}{*}{ V29 } & EV & 19.622 & 0.000 & 5.420 & 65 & 0.000 & 0.964 & 0.178 & 0.609 & 1.320 \\
\hline & NEV & & & 5.371 & 46.460 & 0.000 & 0.964 & 0.180 & 0.603 & 1.326 \\
\hline \multirow{2}{*}{ V30 } & EV & 24.740 & 0.000 & 5.610 & 65 & 0.000 & 1.541 & 0.275 & 0.992 & 2.090 \\
\hline & NEV & & & 5.570 & 52.126 & 0.000 & 1.541 & 0.277 & 0.986 & 2.096 \\
\hline \multirow{2}{*}{ V31 } & EV & 3.442 & 0.068 & 3.211 & 65 & 0.002 & 0.788 & 0.245 & 0.298 & 1.278 \\
\hline & NEV & & & 3.198 & 59.278 & 0.002 & 0.788 & 0.246 & 0.295 & 1.281 \\
\hline \multirow[b]{2}{*}{ V32 } & EV & 3.860 & 0.054 & 2.796 & 65 & 0.007 & 1.341 & 0.480 & 0.383 & 2.299 \\
\hline & NEV & & & 2.805 & 63.088 & 0.007 & 1.341 & 0.478 & 0.386 & 2.297 \\
\hline \multirow{2}{*}{ V33 } & EV & 6.244 & 0.015 & 4.935 & 65 & 0.000 & 1.457 & 0.295 & 0.867 & 2.047 \\
\hline & NEV & & & 4.920 & 61.779 & 0.000 & 1.457 & 0.296 & 0.865 & 2.049 \\
\hline
\end{tabular}


Table D1. Cont.

\begin{tabular}{|c|c|c|c|c|c|c|c|c|c|c|}
\hline & \multirow{3}{*}{ Question Code } & \multicolumn{2}{|c|}{$\begin{array}{c}\text { Levene's Test for Equality } \\
\text { of Variances }\end{array}$} & \multicolumn{7}{|c|}{$t$-Test for Equality of Means } \\
\hline & & \multirow[t]{2}{*}{$\mathbf{F}$} & \multirow[t]{2}{*}{ Sig. } & \multirow[t]{2}{*}{$\mathbf{t}$} & \multirow[t]{2}{*}{ df } & \multirow{2}{*}{$\begin{array}{c}\text { Sig. } \\
\text { (2-Tailed) }\end{array}$} & \multirow{2}{*}{$\begin{array}{c}\text { Mean } \\
\text { Difference }\end{array}$} & \multirow{2}{*}{$\begin{array}{l}\text { Std. Error } \\
\text { Difference }\end{array}$} & \multicolumn{2}{|c|}{$\begin{array}{c}95 \% \text { Confidence Interval of } \\
\text { the Difference }\end{array}$} \\
\hline & & & & & & & & & Lower & Upper \\
\hline \multirow{2}{*}{ V34 } & EV & 2.352 & 0.130 & 4.456 & 65 & 0.000 & 1.307 & 0.293 & 0.721 & 1.892 \\
\hline & NEV & & & 4.450 & 64.148 & 0.000 & 1.307 & 0.294 & 0.720 & 1.893 \\
\hline \multirow[b]{2}{*}{ V35 } & EV & 22.178 & 0.000 & 2.564 & 65 & 0.013 & 1.052 & 0.410 & 0.233 & 1.871 \\
\hline & NEV & & & 2.540 & 45.654 & 0.015 & 1.052 & 0.414 & 0.218 & 1.885 \\
\hline \multirow{2}{*}{ V36 } & EV & 3.585 & 0.063 & 5.163 & 65 & 0.000 & 1.269 & 0.246 & 0.778 & 1.760 \\
\hline & NEV & & & 5.149 & 62.313 & 0.000 & 1.269 & 0.246 & 0.777 & 1.762 \\
\hline \multirow{2}{*}{ V37 } & EV & 0.557 & 0.458 & 7.948 & 65 & 0.000 & 1.695 & 0.213 & 1.269 & 2.121 \\
\hline & NEV & & & 7.932 & 63.350 & 0.000 & 1.695 & 0.214 & 1.268 & 2.122 \\
\hline \multirow{2}{*}{ V38 } & EV & 9.978 & 0.002 & 4.409 & 65 & 0.000 & 1.004 & 0.228 & 0.549 & 1.459 \\
\hline & NEV & & & 4.370 & 47.726 & 0.000 & 1.004 & 0.230 & 0.542 & 1.467 \\
\hline \multirow{2}{*}{ V39 } & EV & 6.279 & 0.015 & 3.221 & 65 & 0.002 & 0.816 & 0.253 & 0.310 & 1.323 \\
\hline & NEV & & & 3.207 & 59.522 & 0.002 & 0.816 & 0.255 & 0.307 & 1.326 \\
\hline \multirow[b]{2}{*}{ V40 } & EV & 21.104 & 0.000 & 3.890 & 65 & 0.000 & 0.963 & 0.247 & 0.468 & 1.457 \\
\hline & NEV & & & 3.852 & 44.878 & 0.000 & 0.963 & 0.250 & 0.459 & 1.466 \\
\hline \multirow{2}{*}{ V41 } & EV & 8.813 & 0.004 & 4.383 & 64 & 0.000 & 0.848 & 0.194 & 0.462 & 1.235 \\
\hline & NEV & & & 4.383 & 54.120 & 0.000 & 0.848 & 0.194 & 0.460 & 1.237 \\
\hline
\end{tabular}


Appendix E.

Table E1. Item-Total Statistics of Original Questionnaire.

\begin{tabular}{|c|c|c|c|c|c|}
\hline Question Code & $\begin{array}{c}\text { Scale Mean If Item } \\
\text { Deleted }\end{array}$ & $\begin{array}{c}\text { Scale Variance If Item } \\
\text { Deleted }\end{array}$ & $\begin{array}{c}\text { Corrected Item-Total } \\
\text { Correlation }\end{array}$ & $\begin{array}{l}\text { Squared Multiple } \\
\text { Correlation }\end{array}$ & $\begin{array}{l}\text { Cronbach's Alpha If } \\
\text { Item Deleted }\end{array}$ \\
\hline V6 & 92.71 & 409.674 & 0.127 & 0.353 & 0.851 \\
\hline V7 & 91.34 & 389.993 & 0.215 & 0.304 & 0.851 \\
\hline V8 & 92.49 & 414.052 & 0.083 & 0.358 & 0.857 \\
\hline V9 & 94.93 & 421.712 & 0.453 & 0.772 & 0.824 \\
\hline V10 & 94.76 & 417.984 & 0.499 & 0.794 & 0.823 \\
\hline V11 & 94.59 & 417.361 & 0.618 & 0.675 & 0.821 \\
\hline V12 & 94.79 & 430.953 & 0.316 & 0.459 & 0.828 \\
\hline V13 & 94.48 & 428.652 & 0.391 & 0.606 & 0.826 \\
\hline V14 & 94.21 & 416.232 & 0.636 & 0.664 & 0.821 \\
\hline V15 & 93.89 & 416.547 & 0.539 & 0.621 & 0.822 \\
\hline V16 & 94.00 & 417.733 & 0.540 & 0.584 & 0.822 \\
\hline V17 & 94.36 & 421.017 & 0.527 & 0.656 & 0.823 \\
\hline V18 & 94.37 & 421.302 & 0.581 & 0.668 & 0.823 \\
\hline V19 & 94.50 & 421.735 & 0.606 & 0.642 & 0.823 \\
\hline V20 & 94.47 & 424.601 & 0.490 & 0.565 & 0.825 \\
\hline V21 & 94.92 & 427.626 & 0.403 & 0.527 & 0.826 \\
\hline V22 & 94.57 & 422.897 & 0.523 & 0.584 & 0.824 \\
\hline V23 & 94.61 & 421.190 & 0.579 & 0.616 & 0.823 \\
\hline V24 & 94.22 & 420.975 & 0.534 & 0.649 & 0.823 \\
\hline V25 & 94.56 & 423.798 & 0.533 & 0.652 & 0.824 \\
\hline V26 & 94.82 & 425.983 & 0.536 & 0.658 & 0.825 \\
\hline V27 & 94.47 & 416.035 & 0.565 & 0.707 & 0.822 \\
\hline V28 & 94.97 & 430.166 & 0.396 & 0.590 & 0.827 \\
\hline V29 & 94.80 & 425.160 & 0.549 & 0.635 & 0.824 \\
\hline V30 & 94.34 & 415.393 & 0.488 & 0.419 & 0.822 \\
\hline V31 & 94.61 & 430.673 & 0.279 & 0.436 & 0.828 \\
\hline V32 & 93.01 & 422.192 & 0.221 & 0.454 & 0.830 \\
\hline V33 & 94.16 & 420.267 & 0.382 & 0.452 & 0.825 \\
\hline V34 & 94.28 & 419.520 & 0.469 & 0.508 & 0.823 \\
\hline V35 & 94.73 & 425.067 & 0.209 & 0.426 & 0.830 \\
\hline V36 & 94.45 & 418.967 & 0.545 & 0.541 & 0.823 \\
\hline V37 & 94.15 & 414.278 & 0.622 & 0.666 & 0.820 \\
\hline V38 & 94.36 & 426.364 & 0.400 & 0.550 & 0.826 \\
\hline V39 & 94.74 & 427.475 & 0.348 & 0.541 & 0.827 \\
\hline V40 & 94.85 & 424.544 & 0.435 & 0.560 & 0.825 \\
\hline V41 & 94.91 & 428.800 & 0.413 & 0.522 & 0.826 \\
\hline
\end{tabular}




\section{Appendix F.}

Table F1. Component Matrix ${ }^{a}$.

\begin{tabular}{ccccc}
\hline \multirow{2}{*}{ Question Code } & \multicolumn{3}{c}{ Component } \\
\cline { 2 - 4 } & $\mathbf{1}$ & $\mathbf{2}$ & $\mathbf{3}$ & $\mathbf{4}$ \\
\hline V11 & 0.726 & -0.246 & -0.145 & -0.200 \\
V14 & 0.742 & 0.011 & 0.210 & -0.217 \\
V15 & 0.658 & 0.106 & -0.280 & -0.241 \\
V16 & 0.672 & 0.020 & -0.053 & -0.294 \\
V17 & 0.703 & -0.401 & 0.083 & -0.064 \\
V18 & 0.694 & -0.313 & 0.201 & -0.210 \\
V19 & 0.741 & -0.075 & 0.209 & -0.130 \\
V22 & 0.569 & 0.003 & 0.270 & 0.542 \\
V23 & 0.660 & -0.310 & 0.182 & 0.388 \\
V24 & 0.626 & 0.058 & -0.259 & 0.377 \\
V25 & 0.669 & -0.269 & -0.099 & 0.046 \\
V26 & 0.571 & 0.633 & 0.203 & 0.100 \\
V27 & 0.666 & 0.551 & 0.134 & -0.210 \\
V29 & 0.598 & 0.178 & 0.332 & -0.028 \\
V36 & 0.621 & 0.187 & -0.471 & 0.029 \\
V37 & 0.701 & 0.053 & -0.486 & \\
\hline
\end{tabular}

Extraction Method: Principal Component Analysis. ${ }^{\text {a }} 4$ components extracted.

\section{Appendix G.}

Table G1. Structure Matrix.

\begin{tabular}{ccccc}
\hline \multirow{2}{*}{ Question Code } & \multicolumn{3}{c}{ Component } & $\mathbf{3}$ \\
\cline { 2 - 5 } & $\mathbf{1}$ & $\mathbf{2}$ & $\mathbf{3}$ & 0.221 \\
V11 & 0.744 & 0.635 & 0.416 & 0.525 \\
V14 & 0.765 & 0.460 & 0.384 & 0.397 \\
V15 & 0.573 & 0.707 & 0.247 & 0.410 \\
V16 & 0.672 & 0.571 & 0.260 & 0.163 \\
V17 & 0.770 & 0.455 & 0.547 & 0.257 \\
V18 & 0.807 & 0.391 & 0.431 & 0.462 \\
V19 & 0.760 & 0.447 & 0.462 & 0.434 \\
V22 & 0.388 & 0.259 & 0.782 & 0.234 \\
V23 & 0.624 & 0.359 & 0.725 & 0.351 \\
V24 & 0.365 & 0.640 & 0.662 & 0.186 \\
V25 & 0.528 & 0.539 & 0.775 & 0.874 \\
V26 & 0.360 & 0.392 & 0.294 & 0.853 \\
V27 & 0.436 & 0.497 & 0.410 & 0.595 \\
V29 & 0.614 & 0.291 & 0.258 & 0.377 \\
V36 & 0.413 & 0.796 & 0.330 & 0.324 \\
V37 & 0.499 & 0.850 & 0.454 & \\
\hline
\end{tabular}

Extraction Method: Principal Component Analysis. Rotation Method: Promax with Kaiser Normalization. 


\section{Appendix $\mathrm{H}$.}

Table H1. Total Variance Explained of Original Questionnaire.

\begin{tabular}{|c|c|c|c|c|c|c|c|}
\hline \multirow{2}{*}{ Component } & \multicolumn{3}{|c|}{ Initial Eigenvalues } & \multicolumn{3}{|c|}{ Extraction Sums of Squared Loadings } & \multirow{2}{*}{$\begin{array}{c}\text { Rotation Sums of Squared Loadings }^{\text {a }} \\
\text { Total }\end{array}$} \\
\hline & Total & $\%$ of Variance & Cumulative \% & Total & $\%$ of Variance & Cumulative $\%$ & \\
\hline 1 & 7.090 & 44.312 & 44.312 & 7.090 & 44.312 & 44.312 & 5.810 \\
\hline 2 & 1.283 & 8.019 & 52.331 & 1.283 & 8.019 & 52.331 & 4.740 \\
\hline 3 & 1.047 & 6.546 & 58.877 & 1.047 & 6.546 & 58.877 & 3.960 \\
\hline 4 & 1.010 & 6.315 & 65.193 & 1.010 & 6.315 & 65.193 & 3.451 \\
\hline 5 & 0.804 & 5.022 & 70.215 & & & & \\
\hline 6 & 0.675 & 4.219 & 74.434 & & & & \\
\hline 7 & 0.669 & 4.181 & 78.615 & & & & \\
\hline 8 & 0.576 & 3.598 & 82.213 & & & & \\
\hline 9 & 0.486 & 3.037 & 85.251 & & & & \\
\hline 10 & 0.453 & 2.834 & 88.084 & & & & \\
\hline 11 & 0.394 & 2.463 & 90.548 & & & & \\
\hline 12 & 0.375 & 2.344 & 92.892 & & & & \\
\hline 13 & 0.340 & 2.128 & 95.020 & & & & \\
\hline 14 & 0.295 & 1.843 & 96.863 & & & & \\
\hline 15 & 0.259 & 1.617 & 98.481 & & & & \\
\hline 16 & 0.243 & 1.519 & 100.000 & & & & \\
\hline
\end{tabular}

Extraction Method: Principal Component Analysis. ${ }^{a}$ When components are correlated, sums of squared loadings cannot be added to obtain a total variance. 


\section{Appendix I.}

Table I1. PCA and K type.

\begin{tabular}{|c|c|c|c|c|c|c|}
\hline Response Code & F1 & F2 & F3 & F4 & Fs & K Type \\
\hline CE1 & 5.476154713 & 0.707855252 & 0.290322581 & -0.872636816 & 3.807647481 & 1 \\
\hline CE2 & 6.054074352 & -0.597528685 & 0.042033236 & -0.237810945 & 4.041413047 & 1 \\
\hline CE3 & 7.159218926 & 0.488967343 & 0.472140762 & 0.688557214 & 4.928379896 & 1 \\
\hline CE4 & 6.031918888 & -0.744042365 & -0.208211144 & 0.105472637 & 4.008253035 & 1 \\
\hline CE5 & 7.028163725 & -0.608120035 & 0.013685239 & -0.07761194 & 4.702260658 & 1 \\
\hline CE6 & 6.345850544 & 1.40776699 & -0.27370479 & 1.844776119 & 4.483293611 & 1 \\
\hline CE7 & 8.638002253 & 2.886142983 & 0.377321603 & 0.68358209 & 6.228003058 & 2 \\
\hline CE8 & 6.28689448 & 0.120035305 & -1.137829912 & 0.189054726 & 4.286637977 & 1 \\
\hline CE9 & 7.443484792 & 0.037952339 & 0.692082111 & -0.227860697 & 5.063045069 & 1 \\
\hline CE10 & 7.539241457 & -0.834951456 & -0.283479961 & 0.213930348 & 5.021358701 & 1 \\
\hline CE11 & 8.861058956 & -0.863195057 & 0.502443793 & -1.925373134 & 5.910572733 & 1 \\
\hline CE12 & 7.476154713 & -0.610767873 & 0.26686217 & 0.296517413 & 5.006946055 & 1 \\
\hline CE13 & 5.233195644 & -0.187113857 & -0.448680352 & 0.171144279 & 3.53352444 & 1 \\
\hline CE14 & 7.950431844 & 1.65842895 & -1.384164223 & -0.618905473 & 5.613420171 & 1 \\
\hline CE15 & 9.503567405 & 0.47749338 & -1.338220919 & 0.034825871 & 6.518074492 & 2 \\
\hline CE16 & 7.973713857 & 0.328331862 & 0.060606061 & 0.302487562 & 5.460286416 & 1 \\
\hline CE17 & 8.761547127 & -0.612533098 & 1.196480938 & 0.047761194 & 5.880277553 & 1 \\
\hline CE18 & 8.007885843 & -1.450132392 & 0.03030303 & 0.698507463 & 5.264735729 & 1 \\
\hline CE19 & 9.909125047 & 1.820829656 & -3.45259042 & -0.129353234 & 6.962130093 & 2 \\
\hline CE20 & 9.310927525 & 0.279788173 & -0.659824047 & -0.800995025 & 6.366465473 & 2 \\
\hline CE21 & 4.221930154 & 0.215357458 & -0.2228739 & 0.537313433 & 2.895402959 & 1 \\
\hline CE22 & 8.689072475 & 1.173874669 & 0.608993157 & 0.648756219 & 6.052934911 & 2 \\
\hline CE23 & 7.418700713 & 0.467784643 & 1.716520039 & 1.233830846 & 5.113529459 & 1 \\
\hline CE24 & 7.684190762 & 1.075904678 & -1.409579668 & -0.099502488 & 5.356240357 & 1 \\
\hline CE25 & 7.514081863 & 0.485436893 & -0.173998045 & -0.085572139 & 5.167178015 & 1 \\
\hline CE26 & 7.780322944 & -1.098852604 & -0.650048876 & 0.543283582 & 5.150899176 & 1 \\
\hline CE27 & 8.708599324 & 0.3451015 & 0.330400782 & 1.59800995 & 5.96509149 & 2 \\
\hline CE28 & 7.759294029 & -0.230361871 & -0.137829912 & 0.256716418 & 5.245469689 & 1 \\
\hline CE29 & 6.80022531 & -0.214474846 & 0.374389052 & -1.20199005 & 4.592907015 & 1 \\
\hline CE30 & 5.497183627 & 0.204766108 & 0.247311828 & -0.253731343 & 3.761258696 & 1 \\
\hline CE31 & 8.465264739 & 0.343336275 & -1.458455523 & 0.602985075 & 5.79054134 & 2 \\
\hline CE32 & 8.998497935 & 0.244483672 & -0.049853372 & -0.44278607 & 6.146546103 & 2 \\
\hline CE33 & 8.194892978 & 0.314210062 & 0.377321603 & 0.693532338 & 5.610431041 & 1 \\
\hline CE34 & 7.446113406 & 0.068843778 & 0.545454545 & 1.903482587 & 5.076226592 & 1 \\
\hline CE35 & 8.285016898 & -1.499558694 & -0.360703812 & -0.899502488 & 5.448948443 & 1 \\
\hline CE36 & 9.57679309 & -0.631950574 & 0.269794721 & -0.946268657 & 6.430031829 & 2 \\
\hline CE37 & 9.197897109 & 0.243601059 & -0.77028348 & 1.021890547 & 6.276831641 & 2 \\
\hline CE38 & 8.178370259 & 1.40070609 & -0.083088954 & 1.309452736 & 5.730514032 & 1 \\
\hline CE39 & 11.06984604 & 0.701676964 & 0.48973607 & -1.649751244 & 7.605428306 & 3 \\
\hline CE40 & 8.776192264 & 1.93027361 & -1.530791789 & 0.093532338 & 6.20178867 & 2 \\
\hline CE41 & 7.220803605 & -0.248896734 & -0.599217986 & 0.541293532 & 4.875339574 & 1 \\
\hline CE42 & 7.533233196 & -1.576345984 & 0.612903226 & 0.115422886 & 4.926899109 & 1 \\
\hline CE43 & 9.034923019 & 1.312444837 & -2.059628543 & -0.980099502 & 6.315368663 & 2 \\
\hline CE44 & 9.42208036 & 1.466019417 & 0.007820137 & 0.894527363 & 6.584641084 & 2 \\
\hline CE45 & 8.59218926 & -1.102383054 & -1.597262952 & 0.168159204 & 5.702831825 & 2 \\
\hline CE46 & 8.380398047 & 0.721977052 & -0.699902248 & 0.344278607 & 5.783493558 & 1 \\
\hline CE47 & 9.280886219 & -0.507502207 & -1.036168133 & -0.858706468 & 6.251483778 & 2 \\
\hline CE48 & 10.89372888 & -1.06619594 & 0.945259042 & -1.0039801 & 7.26733208 & 2 \\
\hline CE49 & 9.875328577 & -1.301853486 & -1.639296188 & 0.013930348 & 6.552009374 & 2 \\
\hline CE50 & 9.479158843 & 0.859664607 & -0.880742913 & -0.105472637 & 6.549386302 & 2 \\
\hline CE51 & 10.26286143 & 1.043248014 & 0.070381232 & -1.873631841 & 7.103231338 & 2 \\
\hline CE52 & 8.340968832 & -1.363636364 & 1.326490714 & -0.888557214 & 5.494156251 & 1 \\
\hline CE53 & 8.929778445 & 1.158870256 & -0.470185728 & 1.27761194 & 6.208374757 & 2 \\
\hline CE54 & 8.684190762 & 1.40423654 & 0.219941349 & 1.186069652 & 6.077104736 & 2 \\
\hline CE55 & 8.911002629 & -0.022947926 & 0.730205279 & 1.270646766 & 6.059925907 & 2 \\
\hline CE56 & 8.208787082 & 0.379523389 & -0.19257087 & 0.688557214 & 5.625406408 & 1 \\
\hline CE57 & 7.936162223 & 0.596646072 & -0.05083089 & 0.887562189 & 5.467368823 & 1 \\
\hline CE58 & 8.078107398 & -0.377758164 & -0.594330401 & -0.629850746 & 5.446637212 & 1 \\
\hline CE59 & 7.973713857 & 0.328331862 & 0.060606061 & 0.302487562 & 5.460286416 & 1 \\
\hline CE60 & 9.646263612 & 0.837599294 & -0.254154448 & -0.132338308 & 6.65987744 & 2 \\
\hline
\end{tabular}


Table I1. Cont.

\begin{tabular}{|c|c|c|c|c|c|c|}
\hline Response Code & F1 & F2 & F3 & F4 & Fs & K Type \\
\hline CE61 & 9.526849418 & -0.72109444 & -0.003910068 & -0.379104478 & 6.386748488 & 2 \\
\hline CE62 & 9.692452122 & 1.594880847 & 1.693059629 & -0.356218905 & 6.780393292 & 2 \\
\hline CE63 & 10.49267743 & -0.667255075 & 0.056695992 & 0.820895522 & 7.050136794 & 2 \\
\hline CE64 & 11.27224934 & -1.837599294 & -1.26001955 & 2.841791045 & 7.413001233 & 3 \\
\hline CE65 & 10.84003004 & -0.556928508 & -1.019550342 & -0.227860697 & 7.300986866 & 3 \\
\hline CE66 & 9.981224183 & -1.025595763 & -0.615835777 & -0.110447761 & 6.658550731 & 2 \\
\hline CE67 & 11.10101389 & -1.641659312 & -2.720430108 & -0.417910448 & 7.350674145 & 2 \\
\hline CE68 & 10.70634623 & 1.586054722 & -2.013685239 & -0.200995025 & 7.474856675 & 3 \\
\hline CE69 & 10.51445738 & 0.154457193 & 0.033235582 & 1.190049751 & 7.165987515 & 2 \\
\hline CE70 & 10.54299662 & 0.331862312 & 0.346041056 & 0.282587065 & 7.207580853 & 2 \\
\hline CE71 & 10.26511453 & -2.035304501 & -0.404692082 & 0.139303483 & 6.726503234 & 2 \\
\hline CE72 & 11.43334585 & 1.537511033 & -3.869012708 & 0.487562189 & 7.948481446 & 3 \\
\hline CE73 & 13.2275629 & 1.991173875 & -2.568914956 & -0.95721393 & 9.251425904 & 3 \\
\hline CE74 & 11.40668419 & 2.134157105 & -1.722385142 & 0.134328358 & 8.014271216 & 3 \\
\hline CE75 & 11.5610214 & 0.094439541 & -0.622678397 & -0.179104478 & 7.870416172 & 3 \\
\hline CE76 & 11.34622606 & 0.73874669 & -0.387096774 & 0.794029851 & 7.80102451 & 3 \\
\hline CE77 & 11.46601577 & 1.590467785 & -0.049853372 & -0.365174129 & 7.98929662 & 3 \\
\hline CE78 & 10.96995869 & 0.329214475 & -0.409579668 & -0.735323383 & 7.498755079 & 2 \\
\hline CE79 & 13.32219302 & -0.361871139 & -0.641251222 & -0.235820896 & 9.011608609 & 3 \\
\hline CE80 & 11.05595193 & -0.589585172 & -1.748778104 & -1.312437811 & 7.456831762 & 2 \\
\hline CE81 & 9.690199024 & 1.375110327 & -1.421309873 & 0.369154229 & 6.752322534 & 2 \\
\hline CE82 & 9.656402554 & -1.340688438 & -0.868035191 & 0.983084577 & 6.393152666 & 2 \\
\hline CE83 & 12.98047315 & 1.276257723 & -0.730205279 & 0.391044776 & 8.978097084 & 3 \\
\hline CE84 & 11.30829891 & 1.812886143 & -1.825024438 & -1.215920398 & 7.923434327 & 3 \\
\hline CE85 & 11.84040556 & -0.481906443 & -0.531769306 & -0.174129353 & 7.989289951 & 3 \\
\hline CE86 & 11.56590312 & -0.464254192 & -1.375366569 & -0.689552239 & 7.810315122 & 2 \\
\hline CE87 & 11.52985355 & -0.433362754 & -0.661779081 & 1.382089552 & 7.777782143 & 3 \\
\hline CE88 & 10.69132557 & 1.274492498 & 0.376344086 & 0.380099502 & 7.424655349 & 2 \\
\hline CE89 & 13.31843785 & 0.915269197 & 0.485826002 & -2.230845771 & 9.158333934 & 3 \\
\hline CE90 & 11.31693579 & 0.467784643 & -1.99315738 & -1.050746269 & 7.763031371 & 3 \\
\hline CE91 & 13.78107398 & -0.483671668 & -1.538611926 & 0.618905473 & 9.30152087 & 3 \\
\hline CE92 & 10.94892978 & 2.095322154 & 0.124144673 & -0.171144279 & 7.699689629 & 2 \\
\hline CE93 & 13.4183252 & 1.300970874 & -0.296187683 & 0.995024876 & 9.278689616 & 3 \\
\hline CE94 & 10.95043184 & -0.233009709 & -0.348973607 & 2.369154229 & 7.409152423 & 2 \\
\hline CE95 & 13.31505821 & 0.527802295 & 0.730205279 & -1.137313433 & 9.109977315 & 3 \\
\hline CE96 & 9.407059707 & 2.763459841 & 1.999022483 & 0.328358209 & 6.738172803 & 2 \\
\hline CE97 & 11.02215546 & -0.203883495 & 0.793743891 & -0.890547264 & 7.462248022 & 2 \\
\hline CE98 & 10.05444987 & 1.833186231 & -2.351906158 & -2.387064677 & 7.095242547 & 2 \\
\hline CE99 & 10.34960571 & 2.154457193 & -1.423264907 & 2.267661692 & 7.279241089 & 3 \\
\hline CE100 & 13.27638002 & 0.329214475 & -0.438905181 & -0.050746269 & 9.064671252 & 3 \\
\hline CE101 & 11.72099136 & 0.448367167 & -0.913000978 & 0.820895522 & 8.017223161 & 3 \\
\hline CE102 & 11.36687946 & -0.53309797 & -2.259042033 & -2.2 & 7.692104921 & 3 \\
\hline CE103 & 14.27938415 & 0.422771403 & -0.204301075 & 0.47960199 & 9.757164862 & 4 \\
\hline CE104 & 11.47465265 & 1.203883495 & -0.921798631 & 0.012935323 & 7.947416298 & 3 \\
\hline CE105 & 13.5148329 & -0.131509267 & 1.027370479 & 0.726368159 & 9.174665725 & 3 \\
\hline CE106 & 12.48291401 & -1.138570168 & -1.730205279 & 1.470646766 & 8.328474568 & 3 \\
\hline CE107 & 15.39466767 & -1.395410415 & -2.091886608 & -0.011940299 & 10.29232816 & 4 \\
\hline CE108 & 15.15133308 & -1.554280671 & -0.530791789 & -0.478606965 & 10.10884186 & 4 \\
\hline CE109 & 13.52797597 & 0.347749338 & 0.848484848 & 0.650746269 & 9.241327383 & 4 \\
\hline CE110 & 13.96432595 & 0.770520741 & -0.282502444 & 0.782089552 & 9.585019142 & 4 \\
\hline CE111 & 13.643635 & 1.92321271 & -1.322580645 & 1.030845771 & 9.501599161 & 4 \\
\hline CE112 & 13.29553136 & 1.520741395 & 0.239491691 & -2.065671642 & 9.220993246 & 3 \\
\hline CE113 & 11.94780323 & 1.396293027 & 0.219941349 & 0.112437811 & 8.292923275 & 3 \\
\hline CE114 & 13.2459632 & 0.79082083 & -1.282502444 & 0.167164179 & 9.099283083 & 3 \\
\hline CE115 & 15.01577169 & 0.051191527 & -1.948191593 & 1.123383085 & 10.19870258 & 4 \\
\hline CE116 & 15.80247841 & -0.277140335 & 0.710654936 & -0.624875622 & 10.70411605 & 4 \\
\hline CE117 & 13.41870071 & 1.45631068 & -0.514173998 & 1.542288557 & 9.294891364 & 4 \\
\hline CE118 & 14.28426587 & 0.231244484 & -1.30400782 & 0.065671642 & 9.736998792 & 4 \\
\hline CE119 & 15.53548629 & 0.048543689 & -0.542521994 & 0.288557214 & 10.56453311 & 4 \\
\hline CE120 & 15.51520841 & 0.54015887 & -0.677419355 & -0.627860697 & 10.61492601 & 4 \\
\hline CE121 & 12.76943297 & -0.315092674 & -1.725317693 & -0.544278607 & 8.646652282 & 3 \\
\hline CE122 & 16.00638378 & -0.294792586 & 0.2971652 & -0.088557214 & 10.84319274 & 4 \\
\hline CE123 & 15.74239579 & 0.05913504 & 0.216031281 & -0.024875622 & 10.7074336 & 4 \\
\hline
\end{tabular}




\section{Appendix J.}

Table J1. PCA Descriptive Statistics.

\begin{tabular}{|c|c|c|c|c|c|c|c|c|c|c|c|c|c|}
\hline & \multirow{2}{*}{$\begin{array}{c}\text { N } \\
\text { Statistic }\end{array}$} & \multirow{2}{*}{$\begin{array}{c}\text { Range } \\
\text { Statistic }\end{array}$} & \multirow{2}{*}{$\begin{array}{l}\text { Minimum } \\
\text { Statistic }\end{array}$} & \multirow{2}{*}{$\begin{array}{l}\text { Maximum } \\
\text { Statistic }\end{array}$} & \multirow{2}{*}{$\begin{array}{c}\text { Sum } \\
\text { Statistic }\end{array}$} & \multicolumn{2}{|c|}{ Mean } & \multirow{2}{*}{$\begin{array}{c}\begin{array}{c}\text { Std. } \\
\text { Deviation }\end{array} \\
\text { Statistic }\end{array}$} & \multirow{2}{*}{$\begin{array}{l}\text { Variance } \\
\text { Statistic }\end{array}$} & \multicolumn{2}{|c|}{ Skewness } & \multicolumn{2}{|c|}{ Kurtosis } \\
\hline & & & & & & Statistic & $\begin{array}{l}\text { Std. } \\
\text { Error }\end{array}$ & & & Statistic & $\begin{array}{l}\text { Std. } \\
\text { Error }\end{array}$ & Statistic & $\begin{array}{l}\text { Std. } \\
\text { Error }\end{array}$ \\
\hline F1 & 123 & $\begin{array}{l}11.784 \\
45362\end{array}$ & $\begin{array}{l}4.2219 \\
30153\end{array}$ & $\begin{array}{l}16.0063 \\
8377769\end{array}$ & $\begin{array}{l}1258.18 \\
475403\end{array}$ & $\begin{array}{l}10.2291 \\
443417\end{array}$ & $\begin{array}{l}0.23458 \\
289429\end{array}$ & $\begin{array}{r}2.60165 \\
0152969\end{array}$ & 6.769 & 0.278 & 0.218 & -0.460 & 0.433 \\
\hline F2 & 123 & $\begin{array}{l}4.9214 \\
47484\end{array}$ & $\begin{array}{l}-2.035 \\
30450\end{array}$ & $\begin{array}{l}2.88614 \\
2983230\end{array}$ & $\begin{array}{c}34.4889 \\
673433\end{array}$ & $\begin{array}{c}0.280398 \\
108482\end{array}$ & $\begin{array}{l}0.09426 \\
215467\end{array}$ & $\begin{array}{l}1.04541 \\
7867551\end{array}$ & 1.093 & 0.080 & 0.218 & -0.479 & 0.433 \\
\hline F3 & 123 & $\begin{array}{l}5.8680 \\
35190\end{array}$ & $\begin{array}{c}-3.869 \\
01277\end{array}$ & $\begin{array}{l}1.99902 \\
2482893\end{array}$ & $\begin{array}{c}-57.145 \\
650048\end{array}$ & $\begin{array}{c}-0.46459 \\
878088\end{array}$ & $\begin{array}{l}0.09230 \\
751755\end{array}$ & $\begin{array}{l}1.02373 \\
9893283\end{array}$ & 1.048 & $0-.508$ & 0.218 & 0.643 & 0.433 \\
\hline F4 & 123 & $\begin{array}{l}5.2288 \\
55721\end{array}$ & $\begin{array}{l}-2.387 \\
06467\end{array}$ & $\begin{array}{c}2.84179 \\
104478\end{array}$ & $\begin{array}{c}10.374 \\
129353\end{array}$ & $\begin{array}{l}0.08434 \\
251506\end{array}$ & $\begin{array}{c}0.08543 \\
292560\end{array}$ & $\begin{array}{l}0.94749 \\
6980313\end{array}$ & 0.898 & -0.090 & 0.218 & 0.594 & 0.433 \\
\hline Fs & 123 & $\begin{array}{l}7.9477 \\
89782\end{array}$ & $\begin{array}{l}2.8954 \\
02959\end{array}$ & $\begin{array}{l}10.8431 \\
9274164\end{array}$ & $\begin{array}{c}859.453 \\
442627\end{array}$ & $\begin{array}{l}6.98742 \\
636282\end{array}$ & $\begin{array}{l}0.16039 \\
946696\end{array}$ & $\begin{array}{l}1.77891 \\
6143930\end{array}$ & 3.165 & 0.236 & 0.218 & -0.532 & 0.433 \\
\hline $\begin{array}{l}\text { Valid N } \\
\text { (listwise) }\end{array}$ & 123 & & & & & & & & & & & & \\
\hline
\end{tabular}




\section{References}

1. Fernández, J.A.; Fernández-Stembridge, L. China's State-Owned Enterprise Reforms: An Industrial and CEO Approach, 1st ed.; Routledge: New York, NY, USA, 2007; p. 21.

2. Bai, J. On regional innovation efficiency: Evidence from panel data of China's different provinces. Reg. Stud. 2013, 47, 773-788. [CrossRef]

3. Han, S.S.; Ofori, G. Construction industry in China's regional economy, 1990-1998. Constr. Manag. Econ. 2001, 19, 189-205. [CrossRef]

4. Hong, J.; Shen, Q.; Xue, F. A multi-regional structural path analysis of the energy supply chain in China's construction industry. Energy Policy 2016, 92, 56-68. [CrossRef]

5. Zhang, J.-X.; Li, H. Analysis on ther eliability assessment of the construction enterprises novation net in China's construction industry. J. Xi'an Univ. Archit. Technol. Nat. Sci. Ed. 2012, 44, 406-411.

6. Zhang, J.-X.; Li, H. Research on the economic growth difference of region construction industry in northwest China. Constr. Econ. 2012, 33, 23-27.

7. Zhang, J.-X.; Li, H.; Zhou, T.-H.; Zhai, Y. The capital structure, business extension and profitable performance of construction enterprises-Civil engineering listed company taken as an example. J. Xi'an Univ. Archit. Technol. Nat. Sci. Ed. 2014, 46, 454-460.

8. Zhang, J.; Xie, H.; Schmidt, K.; Li, H. Using PCA and clustering algorithm to identify powerfactors and transformation pattern of regional construction. In Journal of Computational and Theoretical Nanoscience; Schommers, W., Ed.; Universityof Texas: Arlington, TX, USA, 2015; pp. 1-50.

9. Li, J.; Chiang, Y.; Choi, T.; Man, K. Determinants of efficiency of contractors in Hong Kong and China: Panel data model analysis. J. Constr. Eng. Manag. 2013, 139, 1211-1223. [CrossRef]

10. Shang, G.; Pheng, L.S. Barriers to lean implementation in the construction industry in China. J. Technol. Manag. China 2014, 9, 155. [CrossRef]

11. Xiaoling, Z.; Skitmore, M.; Yuzhe, W.U.; Kunhui, Y.E. A regional construction R\&D evaluation system for china. Constr. Manag. Econ. 2010, 28, 1287-1300.

12. Bonenberg, W.; Wei, X. Green BIM in sustainable infrastructure. Procedia Manuf. 2015, 3, $1654-1659$. [CrossRef]

13. Emmanuel, M.R.; Baker, K. Carbon Management in the Built Environment [Electronic Resource]/Rohinton Emmanuel and Keith Baker; Routledge: Abingdon, UK, 2012.

14. Lewis, J.I. Green innovation in China: China's wind power industry and the global transition to a low-carbon economy. In Contemporary Asia in the World; Columbia University Press: New York, NY, USA, 2013; p. 1.

15. Munier, N.; Jiménez-Sáez, F.; Fernández-Diego, M. Project Management for Environmental, Construction and Manufacturing Engineers a Manual for Putting Theory into Practice; Springer: Dordrecht, The Netherlands; New York, NY, USA, 2013; p. 1.

16. Stubbs, W.; Cocklin, C. Conceptualizing a "Sustainability business model". Organ. Environ. 2008, 21, $103-127$. [CrossRef]

17. Wang, S.H.-M. Sustainable Program Quality Management of International Infrastructure Construction. Available online: http://academic.hep.com.cn/fem/EN/10.15302/J-FEM-2016047 (assessed on 10 January 2017).

18. Xu, D.; Lu, J.W.; Gu, Q. Organizational forms and multi-population dynamics: Economic transition in China. Adm. Sci. Q. 2014, 59, 517-547. [CrossRef]

19. Castro-Lacouture, D.; Irizarry, J.; Ashuri, B.; American Society of Civil Engineers; Construction Institute. Construction Research Congress: Construction in a Global Network. Available online: http:/ /ascelibrary. org/doi/book/10.1061/9780784413517 (assessed on 10 January 2017).

20. McIntyre, C. A Framework for Understanding IAB Output and IAB Management. Available online: http://www.acce-hq.org/images/uploads/IAB_Growth_Management_Model_Version_3.pdf (accessed on 10 January 2017).

21. Jouvet, P.-A.; de Perthuis, C. Green growth: From intention to implementation. Int. Econ. 2013, 134, $29-55$. [CrossRef]

22. Komarkova, L.; Pirozek, P.; Pudil, P. The factors and other characteristics influencing competitiveness of enterprises in countries in the post-transition phase of the economy. Eng. Econ. 2014, 25, 513-521. [CrossRef]

23. Cable, V.; Fallon, M.; Higgins, D. Construction 2025; HM Government: London, UK, 2013; p. 80. 
24. Lucas, L.; Mckenzie, L.; Simon, S.; Hunt, L.; Norris, D.; Pearson, L.; Raynsford, R.H.N.; Manus Ademson, J.W.; Clarks, K.; Barden, A.; et al. Strategy for Sustainable Construction-Progress Report; HM Government \& Strategic Forum for Construction: London, UK, 2009; p. 71.

25. Adamson, D.M.; Pollington, T. Change in the Construction Industry: An Account of the UK Construction Industry Reform Movement 1993-2003; Routledge: London, UK, 2006; p. 162.

26. Adrian, J.J. Business Practices for Construction Management; Elsevier: New York, NY, USA, 1976; p. 425.

27. Akintoye, A.; Goulding, J.; Zawdie, G. Construction Innovation and Process Improvement; Wiley-Blackwell: Hoboken, NJ, USA, 2012; p. 1.

28. Anumba, C.J.; Egbu, C.O.; Carrillo, P.M. Knowledge Management in Construction. Available online: www.petronet.ir/documents/10180/2323250/Knowledge_Management_in_Construction-Chimay_ J._Anumba_Charles_Egbu_Patricia_Carrillo-140512 (assessed on 10 January 2017).

29. Atkin, B.; Borgbrant, J. Performance Improvement in Construction Management; Spon Press: London, UK, 2010; p. 330.

30. Brooker, P.; Wilkinson, S.; Ebooks Corporation. Mediation in the Construction Industry: An International Review; Spon Press: London, UK, 2010; p. 1.

31. Brookes, N. Construction project management. Constr. Manag. Econ. 2013, 31, 1019-1020. [CrossRef]

32. Cain, C.T. Performance Measurement for Construction Profitability; Blackwell Publishing: Hoboken, NJ, USA, $2004 ;$ p. 214.

33. Chinowsky, P.; Songer, A. Organization Management in Construction; Spon Press: London, UK, 2011; p. 204.

34. Zhang, J.; Schmidt, K.; Li, H. An integrated diagnostic framework to manage organization sustainable growth: An empirical case. Sustainability 2016, 8, 23. [CrossRef]

35. Badu, E.; Owusu-Manu, D.-G.; Edwards, D.J.; Holt, G.D. Analysis of strategic issues underpinning the innovative financing of infrastructure within developing countries. J. Constr. Eng. Manag. 2013, 139, $726-737$. [CrossRef]

36. Giang, D.T.H.; Pheng, L.S. Role of construction in economic development: Review of key concepts in the past 40 years. Habitat Int. 2011, 35, 118-125. [CrossRef]

37. Lizarralde, G.; Tomiyoshi, S.; Bourgault, M.; Malo, J.; Cardosi, G. Understanding differences in construction project governance between developed and developing countries. Constr. Manag. Econ. 2013, 31, 711-730. [CrossRef]

38. Kuo, Y. Technology readiness as moderator for construction company performance. Ind. Manag. Data Syst. 2013, 113, 558-572. [CrossRef]

39. Zilber, S.N.; de Araújo, J.B. Small companies innovations in emerging countries: E-business adoption and its business model. J. Technol. Manag. Innov. 2012, 7, 102-115. [CrossRef]

40. Bemelmans, J.; Voordijk, H.; Vos, B.; Buter, J. Assessing buyer-supplier relationship management: Multiple case-study in the dutch construction industry. J. Constr. Eng. Manag. 2012, 138, 163-176. [CrossRef]

41. Park, K.; Kusiak, A. Enterprise resource planning (ERP) operations support system for maintaining process integration. Int. J. Prod. Res. 2005, 43, 3959-3982. [CrossRef]

42. Sexton, M.; Barrett, P. Appropriate innovation in small construction firms. Constr. Manag. Econ. 2003, 21, 623-633. [CrossRef]

43. Wang, X.; Chen, Y.; Liu, B.; Shen, Y.; Sun, H. A total factor productivity measure for the construction industry and analysis of its spatial difference: A case study in China. Constr. Manag. Econ. 2013, 31, 1059-1071. [CrossRef]

44. Korman, T.M.; Huey-King, L. Industry input for construction engineering and management courses: Development of a building systems coordination exercise for construction engineering and management students. Pract. Period. Struct. Des. Constr. 2014, 19, 68-72. [CrossRef]

45. Iammarino, S.; Piva, M.; Vivarelli, M.; von Tunzelmann, N. Technological capabilities and patterns of innovative cooperation of firms in the uk regions. Reg. Stud. 2012, 46, 1283-1301. [CrossRef]

46. Dick, J.; Payne, D. Regional sectoral support: A review of the construction industry, smes and regional innovation strategies across europe. Int. J. Strateg. Prop. Manag. 2005, 9, 55-63.

47. Herliana, S. Regional innovation cluster for small and medium enterprises (SME): A triple helix concept. Procedia Soc. Behav. Sci. 2015, 169, 151-160. [CrossRef]

48. Laihonen, H.; Lonqvist, A.; Metsälä, J. Two knowledge perspectives to growth management. VINE 2015, 45, 473-494. [CrossRef] 
49. AlQahtany, A.; Rezgui, Y.; Li, H. A consensus-based frameworkfor the sustainable urban planning development: "As an approach for saudi arabian cities". Int. J. Environ. Sci. Dev. 2014, 5, 124-131. [CrossRef]

50. Benedetto, F.; Giunta, G.; Mastroeni, L. A maximum entropy method to assess the predictability of financial and commodity prices. Digit. Signal Process. 2015, 46, 19-31. [CrossRef]

51. Bereziński, P.; Jasiul, B.; Szpyrka, M. An entropy-based network anomaly detection method. Entropy 2015, 17, 2367-2408. [CrossRef]

52. Zhang, J.; Xie, H.; Schmidt, K.; Li, H. A new systematic approach to vulnerability assessment of innovation capability of construction enterprises. Sustainability 2016, 8, 25. [CrossRef]

53. Aldana-Bobadilla, E.; Kuri-Morales, A. A clustering method based on the maximum entropy principle. Entropy 2015, 17, 151-180. [CrossRef]

54. Li, B.; Yang, Z.; Su, F. Measurement of vulnerability in human-sea economic system based on set pair analysis: A case study of dalian city. Geogr. Res. 2015, 34, 967-976.

55. Meng, X.-M.; Hu, H.-P. Application of set pair analysis model based on entropy weight tocomprehensive evaluation of water quality. Shuili Xue bao 2009, 40, 257-262.

56. Su, M.R.; Yang, Z.F.; Chen, B. Set pair analysis for urban ecosystem health assessment based on emergy-vitality index. China Environ. Sci. 2009, 29, 892-896. (In Chinese)

57. Li, F.; Wan, N.; Shi, B.; Liu, X.; Guo, Z. The vulnerability measure of tourism industry based on the perspective of "environment-structure" integration a case study of 31 provinces in mainland China. Geogr. Res. 2014, 33, 569-581.

58. Zou, Q.; Zhou, J.Z.; Zhou, C.; Song, L.X.; Guo, J. Comprehensive flood risk assessment based on set pair analysis-variable fuzzy sets model and fuzzy ahp. Stoch. Environ. Res. Risk Assess. 2013, 27, 525-546. [CrossRef]

59. Han, R.; Tong, L.; Tong, W.; Yu, J. Research on vulnerability assessment of human-land system of Anshan city based on set pair analysis. Prog. Geogr. 2012, 31, 344-351.

60. Kohli, A.K.; Jaworski, B.J. Market orientation: The construct, research propositions, and managerial implications. J. Mark. 1990, 54, 1-18. [CrossRef]

61. Deng, S.L.; Dart, J. Measuring market orientation: A multi-factor, multi-item approach. J. Mark. Manag. 1994, 10, 725-742. [CrossRef]

62. Ng, Y.C.; Siu, N.Y.M. Training and enterprise performance in transition: Evidence from China. Int. J. Hum. Resour. Manag. 2004, 15, 878-894. [CrossRef]

63. Deshpande, R. Developing a Market Orientation; Sage Publications: Thousand Oaks, CA, USA, 1999.

64. Shu-Ching, C.; Quester, P.G. Developing a value-based measure of market orientation in an interactive service relationship. J. Mark. Manag. 2005, 21, 779-808.

65. Domenge, R.; Arciniega, L. Development of a short questionnaire for measuring service quality perceptions. DECISION 2015, 42, 11-17. [CrossRef]

66. Silverman, D. Qualitative Research: Theory, Method and Practice; Sage: London, UK; Thousand Oaks, CA, USA, 1997.

67. Luk, C.-L.; Yau, O.H.M.; Chow, R.P.M.; Tse, A.C.B.; Sin, L.Y.M. Stakeholder orientation and business performance: The case of service companies in china. J. Int. Mark. 2005, 13, 89-110. [CrossRef]

68. Li, Y.; Sun, Y.; Liu, Y. An empirical study of soes' market orientation in transitional china. Asia Pac. J. Manag. 2006, 23, 93-113. [CrossRef]

69. Tian, H.; Zhang, J. Regional vulnerability evaluation index system of environmental emergencies in petrochemical industry. Adv. Mater. Res. 2014, 1073-1076, 400-404. [CrossRef]

70. Chen, J.; Yang, X.; Wang, Z.; Zhang, L. Vulnerability and influence mechanisms of rural tourism socio-ecological systems: A household survey in china's qinling mountain area. Tour. Trib. 2015, 30, $64-75$.

71. Ruwanpura, J.; Mohamed, Y.; Lee, S. Construction Research Congress 2010: Innovation for Reshaping Construction Practice. Available online: http://ascelibrary.org/doi/book/10.1061/9780784411094 (assessed on 10 January 2017).

72. Wang, N. The role of the construction industry in China's sustainable urban development. Habitat Int. 2014, 44, 442-450. [CrossRef]

73. Group, E.A.R. Government Construction Strategy? Cabinet Office: London, UK, 2011; p. 43. 
74. Group, S.C. Sustainability Action Plan 2012-2015; HM Managemment: London, UK, 2012; p. 13.

75. Zhang, J.; Schmidt, K.; Li, H. BIM and sustainability education: Incorporating instructional needs into curriculum planning in cem programs accredited by ACCE. Sustainability 2016, 8, 32. [CrossRef]

76. Petri, I.; Beach, T.; Rezgui, Y.; Wilson, I.E.; Li, H. Engaging construction stakeholders with sustainability through a knowledge harvesting platform. Comput. Ind. 2014, 65, 449-469. [CrossRef]

77. Zhang, J.-X.; Li, H. Analysis on structure foundation and its index measurement for the excess capacity of construction industry. J. Xi'an Univ. Archit. Technol. Nat. Sci. Ed. 2013, 45, 105-110.

78. Egan, J. Rethinking Construction: The Egan Report; Construction Task Force: London, UK, 1998; p. 38.

(C) 2017 by the authors; licensee MDPI, Basel, Switzerland. This article is an open access article distributed under the terms and conditions of the Creative Commons Attribution (CC BY) license (http:/ / creativecommons.org/licenses/by/4.0/). 